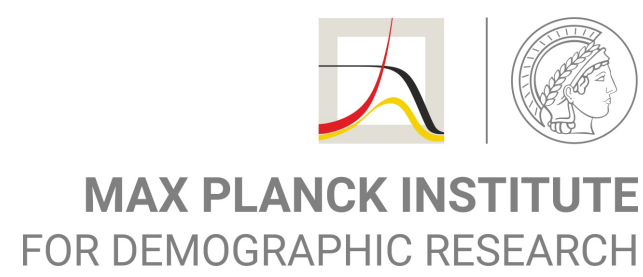

Konrad-Zuse-Strasse 1 · D-18057 Rostock · Germany · Tel +49 (0) 3812081 - 0 · Fax +49 (0) 3812081 - $202 \cdot$ www.demogr.mpg.de

MPIDR Working Paper WP 2020-012 I March 2020

https://doi.org/10.4054/MPIDR-WP-2020-012

\title{
For better or for worse mental health? \\ The role of social networks for exogamous older couples
}

Peter Eibich I eibich@demogr.mpg.de

Chia Liu I liu@demogr.mpg.de

(c) Copyright is held by the authors.

Working papers of the Max Planck Institute for Demographic Research receive only limited review. Views or opinions expressed in working papers are attributable to the authors and do not necessarily reflect those of the Institute. 


\title{
For better or for worse mental health? The role of social networks for exogamous older couples
}

\author{
Peter Eibich ${ }^{1}$ and Chia Liu ${ }^{2}$
}

\begin{abstract}
Objectives: This study tests whether being in an exogamous union, in which one of the partners is an immigrant and the other native, affects an older individual's social networks, and whether the association between exogamy and mental health operates through social networks. We hypothesize that immigrants gain social capital through their native spouse, and thus have better mental health than endogamous immigrants. In contrast, the kin network of exogamous natives is not expanded through their spouse, and we therefore expect their mental health to be lower compared to endogamous natives.
\end{abstract}

Methods: We use longitudinal data from the German Socio-Economic Panel Study on 6,664 couples, 516 of which are exogamous $(7.7 \%)$. We estimate linear correlated random effects regression models to account for observed characteristics and unobserved time-invariant heterogeneity.

Results: Exogamous immigrants have larger social networks due to the expansion of their kin network, while exogamous natives have smaller social networks than endogamous natives. We find that exogamous native women exhibit significantly worse mental health than any other group. Social networks influence mental health but contribute little to these observed differences.

Discussion: Observed differences in mental health between exogamous and endogamous unions can mostly be explained by observed and unobserved characteristics attached to individuals who form exogamous unions. The mental health disadvantage of exogamous native women requires further research.

Keywords: Migration, Family structure, Marriage

\footnotetext{
${ }^{1}$ Max Planck Institute for Demographic Research, Rostock, Germany. E-mail: eibich@demogr.mpg.de.

${ }^{2}$ Max Planck Institute for Demographic Research, Rostock, Germany and School of Geography and Sustainable Development, University of St. Andrews, St. Andrews, United Kingdom. E-mail: ccl26@st-andrews.ac.uk.
} 


\section{Introduction}

European societies are simultaneously graying and rapidly diversifying due to population aging and increasing mobility across borders. Despite a sizable amount of return migration of transitory migrants (Dustmann \& Weiss, 2007), the older immigrant population has risen steadily in most European countries in the past decade, with the number of foreign-born aged 65 and above increasing from roughly 1.4 million to 1.8 million in France from 2009 to 2018, and 0.8 million to 1 million in the United Kingdom in the same years (Eurostat, 2019).

Health disparities between immigrants and non-immigrants have been extensively studied in the literature, with some studies pointing towards a health advantage for immigrants while others report a disadvantage (Carnein et al., 2015; de Valk et al., 2018; Kristiansen et al., 2016; ReusPons et al., 2018). While an immigrant health advantage is typically attributed to positive selection ("healthy immigrant effect", see, e.g., Constant et al., 2018), health disadvantages are often considered to be caused by differentials in immigrants' exposure to risk factors, such as experiences of discrimination (Schunck et al., 2015) or language barriers (Diwan, 2008). Limited social capital (Nyqvist et al., 2013) has received little consideration as a risk factor (Uysal-Bozkir et al., 2015), even though transnational individuals often face constraints barring their enjoyment of a full family network (Burholt et al., 2018).

Regardless of migration background, social interactions with family and friends have been shown to be strongly linked to better mental health for the older population (Burholt et al., 2018; Cohen, 2004; Cramm et al., 2013; House et al., 1988; Shaw et al., 2007; Steptoe \& Fancourt, 2019; Stokes \& Moorman, 2018), consistent with the idea of linked lives (Mortimer \& Shanahan, 2007). Regular social engagement with friends and family is essential to mental health for people of all ages (House et al., 1988), but the relationship of the two intensifies near retirement age or empty nest (Cattan et al., 2005) due to the reshuffling of balance toward personal life as work and child rearing obligations subside.

Immigrants, like non-immigrants, form ties of varying strength through workplace and other social spaces. Family network, however, is likely to differ substantially between immigrants and natives,

due to the event of migration which often entails separation among nuclear, and especially extended, family members. Since geographic proximity is crucial to exchanging physical support 
(Mulder, 2018), and the lack of physical support might indirectly harm mental health as a result of poor physical health, proximity to family members remains pertinent to mental health through both direct and indirect pathways.

Union formation with a native at the destination country offers an opportunity for immigrants to expand their local family network (Koelet et al., 2017; Koelet \& de Valk, 2016; Martinovic et al., 2009; Ryan \& Mulholland, 2013). This intuitively raises the question on whether the social capital gained from mixed unions contributes to the mental health of exogamous immigrants. However, marital homogamy, exemplified by forming a relationship with someone of the same origin, is more commonplace (Qian \& Lichter, 2011). In Germany, individuals of migration background, particularly those from outside of Europe, tend not to partner with Germans, with only around 30\% of Spanish and $12.7 \%$ of Turks doing so (Kalter \& Schroedter, 2010). The selection of those who enter an exogamous union may play a role in mental health in older ages. In addition, exogamous unions are more prone to conflict and dissolution (Milewski \& Kulu, 2014; Saarela \& Finnäs, 2018), which have a negative impact on mental health (Simon, 2002).

In this paper, we examine the relationship between exogamy and mental health at older ages, and ask the following research questions: First, to what extent can we attribute the differences in mental health between endogamous and exogamous couples to the selection process into mixed unions? Second, is the expansion or contraction of social networks through one's spouse one of the mechanisms behind the relationship between exogamy and mental health?

To answer these questions, we investigate the mental health of older adults aged 60 and above, using the German Socio-Economic Panel (GSOEP). We focus our analyses on eight groups of older individuals based on three dimensions: gender, nativity, and union type, namely male and female endogamous natives (German-born, without migration background), exogamous natives, endogamous immigrants (non-German-born), and exogamous immigrants. Social networks are defined as the proximity of one's own and partner's older or younger kin, inside and outside of the household, and one's own number of friends. We first examine the selection into exogamy by exploring the socio-economic and demographic characteristics of those who enter mixed unions. Then we analyze the social networks of exogamous and endogamous natives and immigrants. Lastly, we consider whether social networks can explain differences in mental health for the eight groups. 
Our results show that exogamous native women face a persistent mental health disadvantage compared to endogamous native women, even with social networks and individual effects considered. Social networks contribute little to our understanding of mental health differences among the groups. Instead, selection into different types of union seems to play a role in the gap in mental health between endogamous natives and endogamous immigrants.

This paper builds on a recent study by Milewski and Gawron (2019), which examined associations between exogamous marriages between immigrants and non-immigrants and depressive symptoms. They used cross-country data from the Survey of Health, Ageing and Retirement in Europe (SHARE). They report that exogamous native women experience worse mental health than their endogamous counterparts, while immigrants' gains from exogamous marriage were largely driven by selection on observed confounders.

Our study corroborates these findings and goes beyond the existing evidence by explicitly exploring social networks as a potential mediator.

\section{Data}

The GSOEP is a representative longitudinal household survey for which data is collected annually since 1984 to the present day. The data, at present comprised of over 25,000 individuals surveyed every year, provides household composition, socioeconomic and health indicators for the population residing in Germany. The survey is specifically designed to facilitate research in social sciences pertaining to human behavior and decision making (Goebel et al., 2019).

The GSOEP's oversampling of immigrant households is instrumental for research on this subpopulation. Following historical migration flows, the sample primarily includes immigrants from Turkey, Spain, Italy, Greece and former Yugoslavian countries. Three refreshment samples for the immigrant population were included in 1994, 2013 and 2015. In addition, the refugee survey from 2016, collected by the Institute for Employment Research (IAB) and the Research Centre on Migration, Integration, and Asylum of the Federal Office of Migration and Refugees (BAMF-FZ), was integrated into the GSOEP. 


\subsection{Sample selection and union information}

This study centers on married or cohabitating individuals aged 60 or older. We use information on the migration background and country of birth to categorize individuals as "endogamous natives", “exogamous natives", "endogamous immigrants" and "exogamous immigrants". The information on a respondent's migration background is based on the country of birth, citizenship, as well as parental information for individuals born in Germany. For the purpose of this study, we only compare individuals with a direct migration background (first generation) with individuals without a migration background. A direct migration background implies that the respondent was born outside of Germany and migrated to Germany, while no migration background means that the respondent was born in Germany and their parents were born in Germany as well. We exclude descendants of immigrants (i.e., second or higher generation individuals) from the analysis. It should be noted that if parental information is missing, descendants of immigrants who were born in Germany would be classified as having no migration background. We exclude individuals from the sample if they were born outside of Germany and their partner was also born outside of Germany but in a different country than the respondent due to the small size of this group.

\subsection{Mental health}

Our main outcome variable of interest, mental health, is measured using the 12-Item Short Form survey version 2 (SF-12v2) (Andersen et al., 2007). The SF-12v2 consists of 12 questions covering eight different dimensions of health (i.e. general health, mental health, pain, vitality, role limitations due to emotional problems, role limitations due to physical problems, social functioning, and physical functioning). These eight different subscales were used to derive a physical health summary score (pcs) and a mental health summary score (mcs) (see Andersen, Mühlbacher, Nübling, Schupp, \& Wagner, 2007). These scores take on values between 0 and 100, with higher values representing better health. In the reference population (i.e., the overall GSOEP sample in this case), these scores have a mean of 50 and a standard deviation of 10 . The SF-12v2 scores facilitate comparisons between different subpopulations and are widely used in the social and medical sciences (Gebel \& Voßemer, 2014; Marcus, 2013; Schunck, Reiss, \& Razum, 2015). 


\subsection{Social networks}

We consider social networks both inside and outside of the household. We use household size and co-residence with a (potentially adult) child to operationalize networks within the household, and the number of close friends, and the availability and location of kin of the respondents as well as their partners', for networks outside of the household. Among kin, we separate family members into one's own "older kin" (parents and grandparents), "younger kin" (own children or grandchildren), and "siblings", and those of one's spouse. We construct binary variables for each of these groups, which indicate whether the respondent has one or more kin living outside the household but within at most one hour driving distance.

Household size and co-residence with a child are surveyed in every year. The question on close friends was included in the survey in 2003, 2008, 2011, 2013, 2015 and 2017. Information on kin was only surveyed in 1991, 1996, 2001, 2006, 2011 and 2016. Thus, unfortunately, there is no single wave of the survey in which information on mental health, close friends and kin are all available. Therefore, when analyzing the relationship between mental health and social networks we impute information on social networks using the last observed value, or if not available, the next observed value in later waves. Specifically, we impute information on close friends in 2012, and 2016 using data from 2011, and 2015, respectively. We impute data on close friends in 2002 using data from the 2003 wave, and 2006 from the 2008 wave. Similarly, we impute data on kin networks in 2002 and 2012 using data from 2001 and 2011, respectively. Thus, the final sample for our analysis of the relationship between mental health and social networks covers the years 2002, 2006, 2012 and 2016.

\subsection{Covariates}

In our models, we control for demographic, socioeconomic and geographic characteristics of the respondents. We include indicators of homogamy of the union to address potential selection into exogamous union as well as observable differences that might contribute to the mental health of immigrants and natives. For demographic characteristics, we account for age, age squared, gender, and origin. For socioeconomic variables, we look into household income (quintile), education (in years), and whether or not respondents are still working. For geographic variables, we examine the differences between East and West Germany, and urban and rural settings. 
Previous studies on migration have found large heterogeneity across immigrant groups, but due to the relatively small size of the immigrant population controlling for country of origin would reduce the statistical power of our models considerably. We argue that distinguishing between EU and non-EU immigrants should be sufficient, since these two immigrant groups face very different immigration conditions in terms of mobility of family members. A binary indicator for EU origin, which takes on the value 1 if the country of origin (incl. Germany) was a member state of the European Union at the time of the survey, and zero otherwise, is included.

We categorize the age of migration to Germany by younger than the age of 12, 12 to 17, and 18 or older, commonly used cut-offs in migration research (Choi \& Tienda, 2017). We also consider whether or not an individual is still working and has experienced divorce.

To account for geography, we add an indicator for respondents living in East Germany and distinguish between those living in urban and rural areas, and an interaction of the two.

We consider homogamy with respect to age, education and migration background. Previous studies primarily considered homogamy in terms of ethnicity or race, age, education and religion (see, e.g., Kalmijn, de Graaf, \& Janssen, 2005; Qian \& Lichter, 2018; Zhang \& Van Hook, 2009). There is a high degree of religious homogamy in our sample (over $94 \%$ of Muslims marry other Muslims). Consequently, controlling for religious heterogamy does not affect our estimates (results not shown). We therefore exclude it from our final model.

\section{Methods}

We examine selection into exogamous union among natives and immigrants to gain a better understanding of the underlying processes, using the baseline sample of 31,840 person-year observations covering the period 2002-2016. We regress the indicator for exogamous union on age, the age gap between partners, EU origin, age at migration, years of education as well as the difference in years of education to the partner. Unfortunately, it is not possible to analyze the initial selection into unions, since the formation of most unions is not observed in the data.

Then, we examine differences in social networks by immigrant status and union type by regressing our measures of social networks on a binary indicator for immigrants, a binary indicator for exogamous unions, and an interaction of these two variables. In all models we control for the 
demographic, socioeconomic and geographic control variables described in section 2.4. Due to data availability, we use a smaller sample, with the exact years depending on the outcome (see section 2.3). We estimate linear correlated random-effects (CRE) panel data models (Mundlak, 1978) to account for the longitudinal structure of the data. This approach allows us to control for time-invariant unobserved heterogeneity, which might introduce selection effects, while still providing estimates for time-invariant covariates, e.g., immigration status. Unfortunately, we only observe three cases of transitions from endogamous to exogamous unions or vice versa, and thus we cannot identify any meaningful variation within individuals for union types. Thus, we treat exogamy as a time-constant covariate.

In the third step, we estimate differences in mental health by migrant status and union type. Using the baseline sample of 35,997 observations covering the period 2002-2016, we regress the SF$12 \mathrm{v} 2$ mental health measure on the indicators of migrant status, exogamy and the interaction of these two, while controlling for the covariates described above. We estimate correlated linear random effects models

In the final step of our analysis, we include our indicators of social networks into the model for mental health in step 3 to examine whether observed differences by migrant status and union type can be explained by differences in social networks. For this analysis we use the reduced sample covering the years 2002, 2006, 2012 and 2016.

Finally, we conduct two additional sensitivity analyses to examine potential bias from panel attrition and selective union dissolution. We regress a binary indicator measuring whether a respondent is observed in the survey in the following wave (i.e., in $t+1$ ) on our indicators of migrant status, exogamy and the interaction of these two. Similarly, we examine selective union dissolution by regressing an indicator of whether a respondent is still with the same partner in the next survey wave (conditional on being in the sample) on our indicators of migrant status, exogamy and the interaction. If these indicators are statistically significant, this means that the respective group has a higher likelihood to drop out of the sample or dissolve their union. All estimations are carried out in STATA 16. 


\section{Results}

\subsection{Descriptive statistics}

We observe 6,664 couples between 2002 and 2016, 516 of which are exogamous unions (7.7\%). Of the 806 exogamous individuals (we do not observe both partners in all unions, e.g., because the partner might have declined the personal interview), 404 are immigrants and 402 are natives. While men and women are almost evenly represented among exogamous immigrants (211 men and 193 women), exogamous natives are more frequently male (236 men compared to 166 women).

Table 1 presents the descriptive statistics of the mean and standard deviation of both the mental health score for endogamous and exogamous natives and immigrants. Exogamous immigrants are more likely to be of EU origin (68\%) compared to endogamous immigrants (36\%). On average, exogamous immigrants have been in Germany longer than endogamous immigrants and are more educated than endogamous immigrants (11.7 years of education versus 10.0). A larger proportion of endogamous immigrants are of the lowest income quintile (60\%) compared to exogamous immigrants (29\%) whereas the proportion of exogamous immigrants in the highest income quintile is higher than that of the endogamous immigrants (13\% versus 5\%). Endogamous immigrants live in slightly larger households, likely due to higher co-residence with their child, which, at 46\%, is more than twice as high as any other group.

In terms of social networks outside of the household, exogamous immigrants appear to share more similarities with endogamous Germans. Exogamous immigrants report 4.4 close friends on average, higher than 4.1 for endogamous immigrants. Although exogamous immigrants and endogamous immigrants are both less likely to be living near older kin and siblings, exogamous immigrants gain family members through their partner, with $45 \%$ of exogamous immigrants having partner's siblings and 20\% having partner's older kin living close by, compared to $25 \%$ and $9 \%$ respectively for endogamous immigrants. Both endogamous and exogamous Germans are more likely to have younger kin living nearby, $62 \%$ and $52 \%$, compared to their immigrant counterparts at $47 \%$.

In terms of mental health, endogamous Germans are most advantaged, on average. Endogamous immigrants have the lowest mental health scores among the four groups, at 50.6 compared to 52.6 for endogamous Germans. 


\section{<Table 1 about here $>$}

\subsection{Odds of being in exogamous partnership}

Table 2 shows the odds ratio of being in an exogamous partnership. In general, women are more likely to form exogamous unions compared to men. Immigrant men from an EU country are more than three times as likely, and immigrant women from an EU country are more than twice as likely, to have a native partner than their non-EU origin counterparts. Younger age at arrival in Germany is highly correlated with the odds of partnership with a native, especially for men. Years of education has a positive effect on exogamy for both immigrant men and women. A selection effect on education is not evident for natives. Having been previously divorced is strongly associated with higher odds of being in an exogamous union for all groups. In particular, immigrant female divorcees are 9 times more likely to be in an exogamous union than immigrant women who have not experienced divorce. Immigrant men and women who are more educated than their partner are less likely to be in an exogamous union. Overall, descriptive statistics from Table 1 and odds ratio for exogamy in Table 2 point to a stronger selection effect into exogamy for immigrants compared to natives.

\section{$\langle$ Table 2 about here $>$}

\subsection{Differences in social networks}

In Figure 1, we investigate the differences in social networks among the four groups. The estimates come from a correlated random effects model controlling for demographic, geographic and socioeconomic differences (see Table A.2 in the appendix for a complete list). All differences are relative to endogamous Germans in this figure. Unsurprisingly, immigrants are less likely to live near their own parents or siblings compared to natives, and those who are partnered with immigrants are less likely to live with their in-laws compared to those married to Germans. Endogamous immigrants are more likely to live with at least one child, contributing to overall larger households. When examining heterogeneity by gender, the patterns are qualitatively similar (see Tables A.3 and A.4 in the online appendix).

$<$ Figure 1 about here $>$ 


\subsection{Mental Health}

In Figure 2, we show the differences between endogamous and exogamous natives and immigrants in mental health separately by sex, with endogamous men and women as the reference groups. The full regression results for the models are shown in Tables A.5 and A.6 in the online appendix. In the basic model without any control variables, we find that endogamous immigrants' mental health is significantly lower than endogamous natives' for both men and women. Exogamous immigrants exhibit lower mental health than endogamous natives as well, however, the difference is only significant when we control for additional covariates and only for men. Interestingly, exogamous native men have similar mental health as their endogamous counterparts, while the mental health of exogamous native women is significantly lower compared to endogamous native women. The magnitude of this difference corresponds to 0.2 standard deviations in mental health. Once we account for socioeconomic characteristic, differences between immigrants and natives become smaller and are no longer statistically significant. In contrast, the difference between endogamous native women and exogamous native women remains significant. Overall, these findings confirm a "native strain" from an exogamous union for women.

\subsection{Mental health and social networks}

For Figure 3, we re-estimate our CRE model using the restricted sample (covering the years 2002, 2006, 2012 and 2016) including our indicators of social networks as covariates to examine whether they can explain differences in mental health observed between immigrants and natives as well as endogamous and exogamous couples. The estimated coefficients are shown in Tables A.7-A.8 in the online appendix. In the restricted sample, the difference between endogamous native men and endogamous immigrant men is never statistically significant. In contrast, in all models, exogamous native women have lower mental health than endogamous native women. Taking differences in social networks into account does not seem to affect the estimates for men in any meaningful way. For women, we note that controlling for social networks reduces the gap between endogamous native women and endogamous immigrant women. However, the difference between the two groups is never statistically significant. Looking at the estimated associations between social networks and mental health, we note that having older kin nearby is clearly negative for mental health of women. A plausible explanation is that middle-aged and older women living close to their parents and grandparents are often expected to shoulder care responsibilities, which have 
been shown to negatively affect the caregiver's mental health (Schmitz \& Westphal, 2015). Similarly, living close to older kin of the spouse is negatively associated with mental health in both models, but the association is only significant for men at the 10 percent level.

$<$ Figure 3 about here>

\subsection{Sensitivity analyses}

The sensitivity analyses are shown in Table A.9 in the online appendix. As expected, we find that migrants and exogamous natives exhibit both higher panel attrition and a higher propensity of union dissolution. However, once we control for the observed individual characteristics and unobserved heterogeneity in our CRE regression models, these significant differences disappear, thus alleviating our concerns about potential bias from attrition.

\section{Discussion}

Germany, the world's second most popular migrant destination, hosts over 12 million resident immigrants (United Nations, 2018), many of whom arrived as guest workers between 1961 to 1973 (Carnein et al., 2015). Those who have formed consistent labor force attachment were most likely to have stayed (Yahirun, 2014) and have now aged into advanced life stages in Germany. Disparity between their mental health compared to ethnic Germans' remains to be little explored, mainly due to their limited numbers in the past rendering quantitative analyses difficult.

In this study, we found that there is a selection effect for immigrants who form exogamous unions by observable characteristics, such as longer duration of stay in Germany, being of European origin, and being more educated, all of which are characteristics associated with better mental health. Our models also suggest that there are perhaps unobservable characteristics negative to mental health that are attached to immigrants in endogamous unions, which might explain a large proportion of the gap in mental health between endogamous natives and immigrants.

In line with earlier findings reported by Milewski and Gawron (2019), we find a large and persistent difference in the mental health of exogamous native women compared to their endogamous counterparts, despite little evidence for selection of natives into exogamous unions. In contrast, exogamous native men exhibit similar health as endogamous native men. This finding opens up new questions on whether women in particular are more negatively affected by 
experiences attached with exogamous unions. In the case of poorer marital quality, marital discord has been shown to have a more pronounced impact on women's mental health (Kiecolt-Glaser \& Newton, 2001), and for German women, it is possible that cultural conflicts or different expectations in the gender division of household and market work can arise with partners from more socially conservative backgrounds (Batalova \& Cohen, 2002).

We find that social ties have the potential to both promote and strain mental health, consistent with results from previous studies. We find surprisingly little difference between the availability of one's own and spouse's kin and their connection with one's mental health, but we do observe a generational difference. This suggests that the direction of care matters. For individuals who are 60 years or older, providing care to even older family members may be deleterious to one's mental health.

Although social networks influence mental health of older individuals, we find little evidence that supports social networks as the main driver behind the relationship between exogamy and mental health. The gap in mental health between endogamous German women and exogamous German women remains robust even with social network variables considered. If anything, our results even suggest that immigrants and exogamous natives are advantaged by their comparatively smaller social networks, since they are less likely to live close to older kin (both own and spouse's). Yet, although our evidence mainly points to selection effects, there might be other unobserved pathways between exogamy and mental health for older individuals.

From the immigrant perspective, it is difficult to determine the direction of causality between exogamy and mental health. Exogamy can be seen as a "barrier-breaking" invitation into the destination society (Rodríguez-García, 2015). In this case, exogamy may indirectly enhance mental health by providing more local networks and reducing social distance between minority and majority group. However, more integrated immigrants might be simultaneously more likely to form a partnership with a native and have better mental health as a result of their already high level of integration pre-union. In this scenario, exogamy is only a sign that they've passed the "litmus test" (Alba \& Nee, 2009; Qian et al., 2018) of integration, rather than a vehicle to better mental health. Moreover, exogamous marriages are more prone to conflict and dissolution (Milewski \& Kulu, 2014; Saarela \& Finnäs, 2018), yet most older people in our sample are unlikely to have only recently formed their union, thus reducing the role of conflict as a negative mediator 
and possibly introducing survivor's bias. As a result of very few individuals switching from endogamous to exogamous union and vice versa, we are unable to make definitive remarks on the direction of causality between exogamy and mental health.

Our analyses excluded individuals born in Germany with migration background, i.e. the second generation. Second generation individuals in Germany experience unique challenges, such as higher self-perception of discrimination (Aichberger et al., 2015), yet do not face first generation difficulties, such as linguistic barriers and non-recognition of their qualifications in the labor market. Their mental health risk factors require separate scrutiny and are beyond the scope of this paper.

To better disentangle the link between exogamy and mental health, a larger sample of individuals who change their status from singlehood to exogamous or endogamous union should be examined to pin down within-subject variations across time. Looking at the linkage between social networks and mental health in old age in various institutional settings would enhance our understanding of the relationship between the two. We also recommend future research to consider a wider range of social contacts, in addition to friends and family, such as neighbors or social workers and their roles in facilitating healthy aging. 


\section{References}

Aichberger, M. C., Heredia Montesinos, A., Bromand, Z., Yesil, R., Temur-Erman, S., Rapp, M. A., Heinz, A., \& Schouler-Ocak, M. (2015). Suicide attempt rates and intervention effects in women of Turkish origin in Berlin. European Psychiatry, 30(4), 480-485. https://doi.org/10.1016/j.eurpsy.2014.12.003

Alba, R. D., \& Nee, V. (2009). Remaking the American Mainstream: Assimilation and Contemporary Immigration. Harvard University Press.

Andersen, H. H., Mühlbacher, A., Nübling, M., Schupp, J., \& Wagner, G. G. (2007). Computation of Standard Values for Physical and Mental Health Scale Scores Using the SOEP Version of SF$12 v 2$ (pp. 171-182). https://www.ratswd.de/download/schmollers/2007_127/Schmollers_2007_1_S171.pdf

Batalova, J. A., \& Cohen, P. N. (2002). Premarital Cohabitation and Housework: Couples in CrossNational Perspective. Journal of Marriage and Family, 64(3), 743-755. https://doi.org/10.1111/j.1741-3737.2002.00743.x

Burholt, V., Dobbs, C., \& Victor, C. (2018). Social support networks of older migrants in England and Wales: The role of collectivist culture. Ageing \& Society, 38(7), 1453-1477. https://doi.org/10.1017/S0144686X17000034

Carnein, M., Milewski, N., Doblhammer, G., \& Nusselder, W. J. (2015). Health inequalities of immigrants: Patterns and determinants of health expectancies of Turkish migrants living in Germany. In G. Doblhammer (Ed.), Health among the elderly in Germany (Series on Population Studies by the Federal Institute for Population Research, Vol. 46). Opladen, Berlin, Toronto: Barbara Budrich.

Cattan, M., White, M., Bond, J., \& Learmouth, A. (2005). Preventing social isolation and loneliness among older people: A systematic review of health promotion interventions. Ageing \& Society, 25(1), 41-67. https://doi.org/10.1017/S0144686X04002594

Choi, K. H., \& Tienda, M. (2017). Intermarriage and the Lifecycle Timing of Migration. International Migration Review. https://doi.org/10.1111/imre.12326

Cohen, S. (2004). Social Relationships and Health. American Psychologist, 59(8), 676-684. https://doi.org/10.1037/0003-066X.59.8.676

Constant, A. F., García-Muñoz, T., Neuman, S., \& Neuman, T. (2018). A "healthy immigrant effect" or a "sick immigrant effect"? Selection and policies matter. The European Journal of Health Economics, 19(1), 103-121. https://doi.org/10.1007/s10198-017-0870-1 
Cramm, J. M., van Dijk, H. M., \& Nieboer, A. P. (2013). The Importance of Neighborhood Social Cohesion and Social Capital for the Well Being of Older Adults in the Community. The Gerontologist, 53(1), 142-152. https://doi.org/10.1093/geront/gns052

de Valk, H. A. G., Fokkema, T., \& Apt, W. (2018). Health among older populations of migrant origin. In Final Report: Demographic change and migration. https://www.jp-demographic.eu/wpcontent/uploads/2015/06/full-report-fast-track-migration.pdf

Diwan, S. (2008). Limited English proficiency, social network characteristics, and depressive symptoms among older immigrants. The Journals of Gerontology. Series B, Psychological Sciences and Social Sciences, 63(3), 184-191. https://doi.org/10.1093/geronb/63.3.s184

Dustmann, C., \& Weiss, Y. (2007). Return Migration: Theory and Empirical Evidence from the UK. British Journal of Industrial Relations, 45(2), 236-256. https://doi.org/10.1111/j.14678543.2007.00613.x

Eurostat. (2019). Population on 1 January by age group, sex and country of birth (migr_pop3ctb). https://ec.europa.eu/eurostat/web/population-demography-migration-projections/data/database

Goebel, J., Grabka, M. M., Liebig, S., Kroh, M., Richter, D., Schröder, C., \& Schupp, J. (2019). The German Socio-Economic Panel (SOEP). Jahrbücher Für Nationalökonomie Und Statistik, 239(2), 345-360. https://doi.org/10.1515/jbnst-2018-0022

House, J. S., Landis, K. R., \& Umberson, D. (1988). Social relationships and health. Science, 241(4865), 540-545. https://doi.org/10.1126/science.3399889

Kalmijn, M., de Graaf, P. M., \& Janssen, J. P. G. (2005). Intermarriage and the risk of divorce in the Netherlands: The effects of differences in religion and in nationality, 1974-94. Population Studies, 59(1), 71-85. https://doi.org/10.1080/0032472052000332719

Kalter, F., \& Schroedter, J. H. (2010). Transnational marriage among former labour migrants in Germany. Zeitschrift Für Familienforschung, 22(1), 11-36.

Kiecolt-Glaser, J. K., \& Newton, T. L. (2001). Marriage and health: His and hers. Psychological Bulletin, 127(4), 472-503. https://doi.org/10.1037/0033-2909.127.4.472

Koelet, S., \& de Valk, H. A. (2016). Social networks and feelings of social loneliness after migration: The case of European migrants with a native partner in Belgium. Ethnicities, 16(4), 610-630. https://doi.org/10.1177/1468796816638398

Koelet, S., Mol, C. V., \& de Valk, H. a. G. (2017). Social embeddedness in a harmonized Europe: The social networks of European migrants with a native partner in Belgium and the Netherlands. Global Networks, 17(3), 441-459. https://doi.org/10.1111/glob.12123 
Kristiansen, M., Razum, O., Tezcan-Güntekin, H., \& Krasnik, A. (2016). Aging and health among migrants in a European perspective. Public Health Reviews, 37(1), 20. https://doi.org/10.1186/s40985-016-0036-1

Martinovic, B., van Tubergen, F., \& Maas, I. (2009). Dynamics of Interethnic Contact: A Panel Study of Immigrants in the Netherlands. European Sociological Review, 25(3), 303-318. https://doi.org/10.1093/esr/jcn049

Milewski, N., \& Gawron, A. (2019). Is there an association between marital exogamy of immigrants and nonmigrants and their mental health? A two-partners approach. Demographic Research, 40(21), 561-598. https://doi.org/10.4054/DemRes.2019.40.21

Milewski, N., \& Kulu, H. (2014). Mixed Marriages in Germany: A High Risk of Divorce for ImmigrantNative Couples. European Journal of Population, 30(1), 89-113. https://doi.org/10.1007/s10680013-9298-1

Mortimer, J. T., \& Shanahan, M. J. (2007). Handbook of the Life Course. Springer Science \& Business Media.

Mulder, C. H. (2018). Putting family centre stage: Ties to nonresident family, internal migration, and immobility. Demographic Research, 39, 1151-1180. https://doi.org/10.4054/DemRes.2018.39.43

Mundlak, Y. (1978). On the Pooling of Time Series and Cross Section Data. Econometrica, 46(1), 69-85. https://doi.org/10.2307/1913646

Nyqvist, F., Forsman, A. K., Giuntoli, G., \& Cattan, M. (2013). Social capital as a resource for mental well-being in older people: A systematic review. Aging \& Mental Health, 17(4), 394-410. https://doi.org/10.1080/13607863.2012.742490

Qian, Z., \& Lichter, D. T. (2011). Changing Patterns of Interracial Marriage in a Multiracial Society. Journal of Marriage and Family, 73(5), 1065-1084. https://doi.org/10.1111/j.17413737.2011.00866.x

Qian, Z., \& Lichter, D. T. (2018). Marriage Markets and Intermarriage: Exchange in First Marriages and Remarriages. Demography, 55(3), 849-875. https://doi.org/10.1007/s13524-018-0671-x

Qian, Z., Lichter, D. T., \& Tumin, D. (2018). Divergent Pathways to Assimilation? Local Marriage Markets and Intermarriage Among U.S. Hispanics. Journal of Marriage and Family, 80(1), 271288. https://doi.org/10.1111/jomf.12423

Reus-Pons, M., Mulder, C. H., Kibele, E. U. B., \& Janssen, F. (2018). Differences in the health transition patterns of migrants and non-migrants aged 50 and older in southern and western Europe (20042015). BMC Medicine, 16(1), 57. https://doi.org/10.1186/s12916-018-1044-4 
Rodríguez-García, D. (2015). Intermarriage and Integration Revisited: International Experiences and Cross-Disciplinary Approaches. The ANNALS of the American Academy of Political and Social Science, 662(1), 8-36. https://doi.org/10.1177/0002716215601397

Ryan, L., \& Mulholland, J. (2013). 'Wives Are the Route to Social Life': An Analysis of Family Life and Networking amongst Highly Skilled Migrants in London. Sociology, 48(2). https://journals.sagepub.com/doi/full/10.1177/0038038512475109?casa_token=weV493bDZHM AAAAA\%3A6X14bIs8QhPW3TjFH7eKruejVV8TNtbXNIFv_hkW6nr_ySnkVMnBaUjhVKhw SPJAld6NvJccRx0wlsUC

Saarela, J., \& Finnäs, F. (2018). Ethno-Linguistic Exogamy and Divorce: Does Marital Duration Matter? Sociological Focus, 51(4), 279-303. https://doi.org/10.1080/00380237.2018.1431506

Schmitz, H., \& Westphal, M. (2015). Short- and medium-term effects of informal care provision on female caregivers' health. Journal of Health Economics, 42, 174-185. https://doi.org/10.1016/j.jhealeco.2015.03.002

Schunck, R., Reiss, K., \& Razum, O. (2015). Pathways between perceived discrimination and health among immigrants: Evidence from a large national panel survey in Germany. Ethnicity \& Health, 20(5), 493-510. https://doi.org/10.1080/13557858.2014.932756

Shaw, B. A., Krause, N., Liang, J., \& Bennett, J. (2007). Tracking Changes in Social Relations Throughout Late Life. The Journals of Gerontology: Series B, 62(2), S90-S99. https://doi.org/10.1093/geronb/62.2.S90

Simon, R. W. (2002). Revisiting the Relationships among Gender, Marital Status, and Mental Health. American Journal of Sociology, 107(4), 1065-1096. https://doi.org/10.1086/339225

Steptoe, A., \& Fancourt, D. (2019). Leading a meaningful life at older ages and its relationship with social engagement, prosperity, health, biology, and time use. PNAS, 116(4), 1207-1212.

Stokes, J. E., \& Moorman, S. M. (2018). Influence of the Social Network on Married and Unmarried Older Adults' Mental Health. The Gerontologist, 58(6), 1109-1113. https://doi.org/10.1093/geront/gnx151

United Nations. (2018). World migration report 2018. UNITED NATIONS PUBNS.

Uysal-Bozkir, Ö., Fokkema, T., MacNeil-Vroomen, J. L., van Tilburg, T. G., \& de Rooij, S. E. (2015). Translation and Validation of the De Jong Gierveld Loneliness Scale Among Older Migrants Living in the Netherlands. The Journals of Gerontology. Series B, Psychological Sciences and Social Sciences, 72(1), 109-119. https://doi.org/10.1093/geronb/gbv044

Yahirun, J. J. (2014). Take Me "Home”: Return Migration among Germany’s Older Immigrants. International Migration, 52(4), 231-254. https://doi.org/10.1111/imig.12009 
Zhang, Y., \& Van Hook, J. (2009). Marital Dissolution Among Interracial Couples. Journal of Marriage and Family, 71(1), 95-107. https://doi.org/10.1111/j.1741-3737.2008.00582.x 


\section{Tables and Figures}

Table 1. Descriptive Statistics

Table 1: Descriptive statistics

Mental health (SF-12)

Age gap to partner

EU origin

Age at arrival in Germany: 0-11

Age at arrival in Germany: 12-17

Years of education

Difference in education to partner

Income quintile
Germans

\begin{tabular}{cc} 
Endogamous & Exogamous \\
\hline 52.62 & 51.15 \\
$(9.94)$ & $(10.43)$ \\
0.96 & 2.76 \\
$(5.23)$ & $(8.22)$
\end{tabular}

Migrants

\begin{tabular}{cc}
\hline Endogamous & Exogamous \\
\hline 50.58 & 51.22 \\
$(10.44)$ & $(10.58)$ \\
1.47 & 1.41 \\
$(5.64)$ & $(5.83)$ \\
0.36 & 0.68 \\
$(0.48)$ & $(0.47)$ \\
0.01 & 0.10 \\
$(0.08)$ & $(0.30)$ \\
0.01 & 0.09 \\
$(0.11)$ & $(0.29)$ \\
10.04 & 11.71 \\
$(2.31)$ & $(2.71)$ \\
0.06 & -0.13 \\
$(2.01)$ & $(2.85)$
\end{tabular}

11.97

(2.80)

0.14

(2.84)

(2.64)
0.30

(0.46)

0.13

$(0.33)$

0.29

(0.46)

(0.38)

3.99

(3.57)

(4.10)

0.14

$(0.35)$

0.10

$(0.30)$

0.43

(0.50)

0.25

(0.44)

0.52

(0.50)

2.54

(0.88)

0.22

(0.41)

0.60

0.29

(0.49)

(0.45)

0.05

0.13

(0.22)

(0.34)

0.08

0.23

(0.27)

(0.42)

4.07

4.41

(4.59)

(4.47)

0.09

0.11

(0.29)

(0.31)

0.10

0.20

(0.30)

(0.40)

0.25

0.27

(0.43)

(0.45)

0.25

0.45

(0.43)

(0.50)

0.47

0.47

(0.50)

(0.50)

3.54

2.62

(1.68)

(0.98)

0.46

0.22

(0.39)

(0.50)

(0.42)

Source: SOEPv34, own calculations. The table provides mean values with standard deviations in parentheses. 
Table 2. Analysis of Exogamy

Table 2: Analysis of exogamy

\section{$\underline{\text { Odds ratios }}$}

Age

Age gap to partner

Country of origin in EU

Age at arrival in Germany: 0-11

Age at arrival in Germany: 12-17

Years of education

Difference in education to partner

Previously divorced

Baseline odds

\begin{tabular}{cc}
\hline \multicolumn{2}{c}{ Dependent variable: } \\
\hline \multicolumn{2}{c}{ Germans } \\
\hline Men & Women \\
\hline 0.987 & 0.990 \\
$(0.011)$ & $(0.014)$ \\
$1.045^{*}$ & 1.046 \\
$(0.019)$ & $(0.031)$
\end{tabular}

$\begin{array}{r}\text { Migrants } \\ \hline\end{array}$

\begin{tabular}{cc}
\hline Men & Women \\
\hline 1.000 & 1.013 \\
$(0.020)$ & $(0.027)$ \\
0.980 & 1.003
\end{tabular}

$(0.031) \quad(0.036)$

$(0.036)$

3.051*** 2.209*

(0.877) (0.742)

$17.938 * * \quad 17.233 *$

(18.296) (20.843)

$12.256 * * \quad 5.723 *$

(10.156) (4.677)

$1.350 * * * \quad 1.445 * * *$

$(0.103) \quad(0.120)$

$0.830 * \quad 0.769 * * *$

(0.062) (0.054)

$5.047 * * * \quad 9.150 * * *$

(1.760) (3.954)

$0.010 * * * \quad 0.013 * * *$

(0.005) (0.006)

\begin{tabular}{llllc}
$\mathrm{N}$ & 15,915 & 12,985 & 1,637 & 1,303 \\
\hline \hline
\end{tabular}

Source: SOEPv34, own calculations. Each column presents estimates of odds ratios from a separate logistic regression model. Standard error in parentheses. Age was centered around 60. Years of education was centered around the group mean. $\dagger \mathrm{p}<0.1, * \mathrm{p}<0.05$, ** $\mathrm{p}<0.01 ; * * * \mathrm{p}<0.001$. 


\section{Figure Captions}

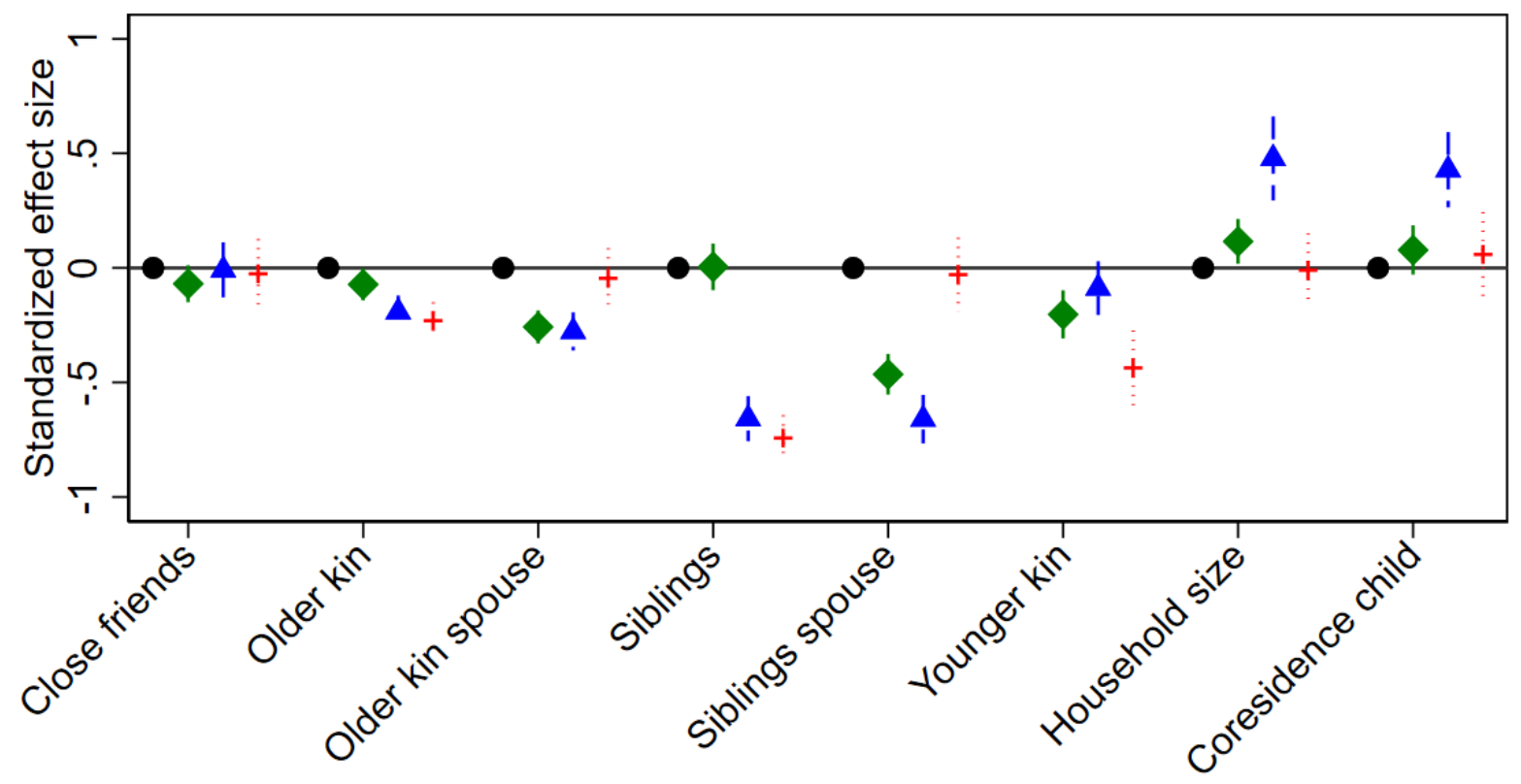
- Endogamous natives (reference group)
Exogamous natives
$95 \% \mathrm{Cl}$
$\Delta$ Endogamous immigrants
$----95 \% \mathrm{Cl}$
+ Exogamous immigrants
$95 \% \mathrm{Cl}$

Fig. 1 Differences in social networks. The figure shows estimated differences between groups in social networks. All estimates come from linear correlated random effects models controlling for age, age squared, gender, EU origin, age at arrival in Germany, East Germany, rural area, an interaction between East Germany and rural area, working status, education in years and income in quintiles. All outcome variables are standardized. All estimated differences are relative to endogamous natives. Markers show point estimates and lines show $95 \%$ confidence intervals. 


\section{Effect on Mental Health Score}
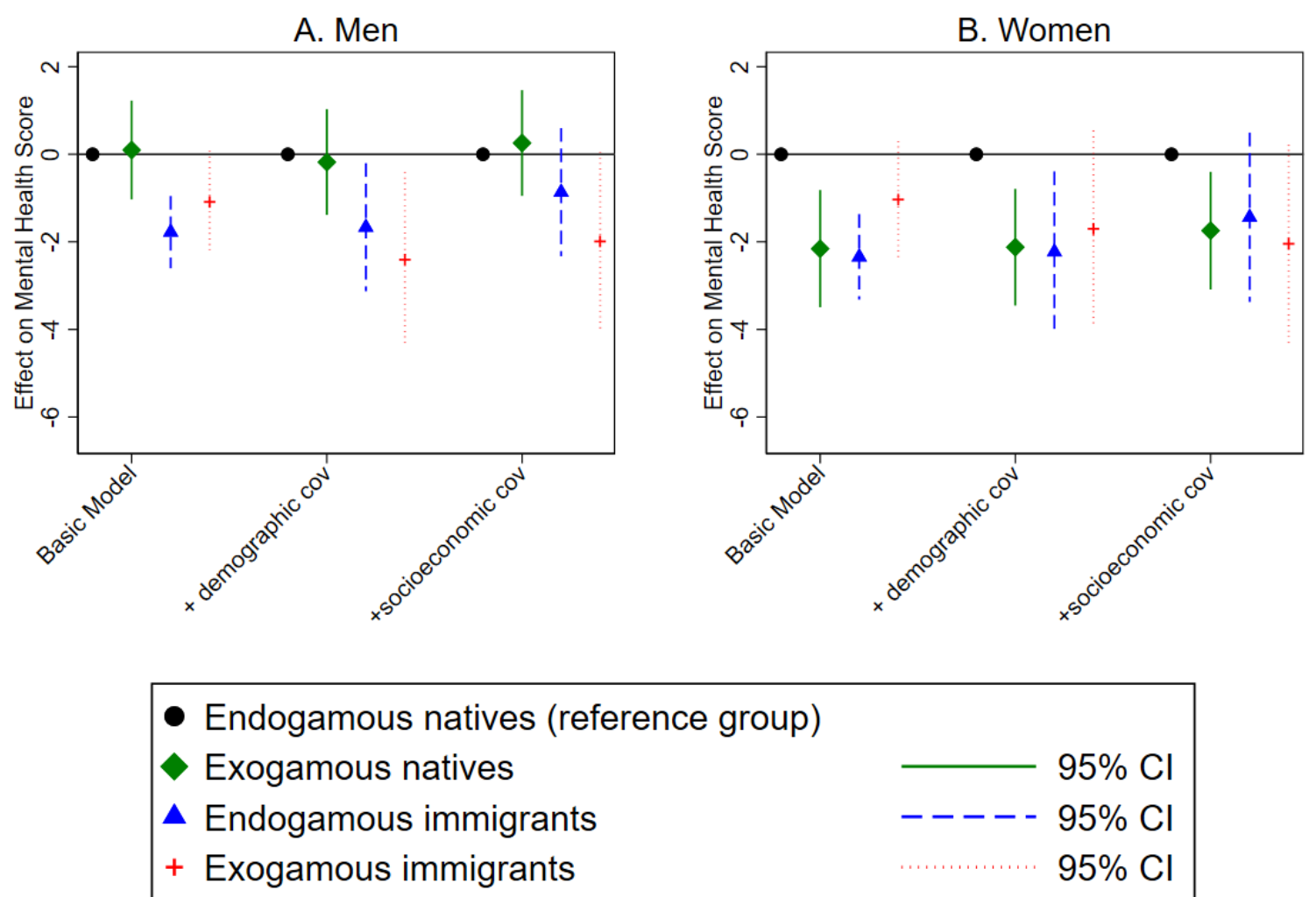

Fig. 2 Differences in mental health by gender. The figure shows estimated differences between groups in mental health. All estimates come from linear correlated random effects models. The basic model does not include any additional controls. "Demographic cov" includes demographic characteristics as control variables, i.e., age, age squared, gender, EU origin, age at arrival in Germany, East Germany, rural area, and an interaction between East Germany and rural area. "Socioeconomic cov" additionally includes control variables for working status, education in years and income in quintiles. Mental health is measured using the SF-12 mental score (mcs). The models were estimated on a dataset covering the years 2002, 2004, 2006, 2008, 2010, 2012, 2014 and 2016. All estimated differences are relative to endogamous natives. Markers show point estimates and lines show $95 \%$ confidence intervals. 


\section{Effect on Mental Health Score}
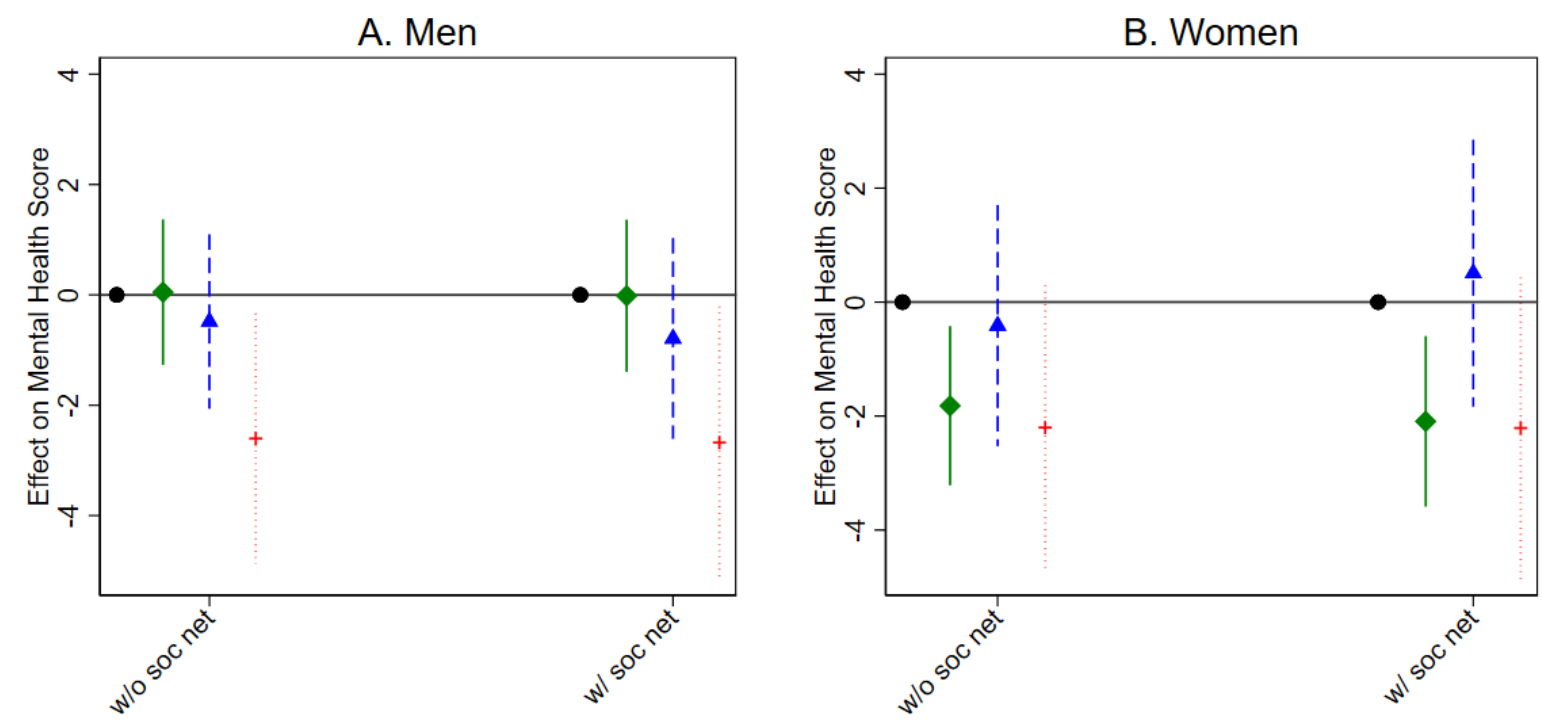

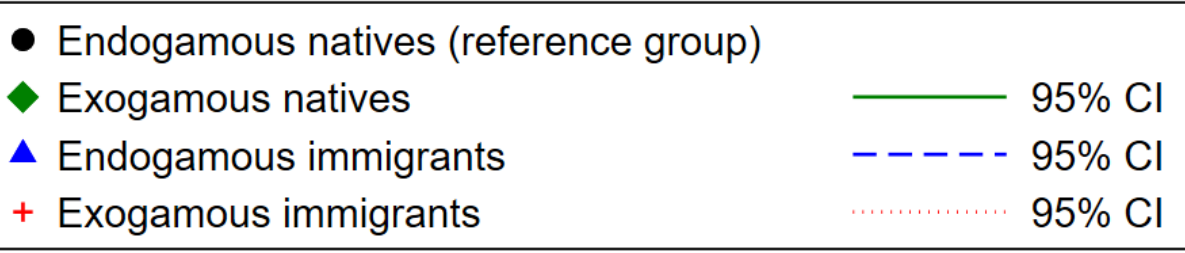

Fig. 3 Mental health and social networks. The figure shows estimated differences between groups in mental health. All estimates come from linear correlated random effects models controlling for age, squared age, gender, EU origin, age at arrival in Germany, East Germany, rural area, an interaction between East Germany and rural area, working status, education in years and income in quintiles. Mental health is measured using the SF-12 mental score. The model labelled "w/o socnet" does not control for social networks variables, the model "w/ socnet" additionally controls for the social network variables shown in Figure 1. The models were estimated on a dataset including the years 2002, 2006, 2012 and 2016. All estimated differences are relative to endogamous natives. Markers show point estimates and lines show $95 \%$ confidence intervals. 


\section{Online Appendix}

Additional Tables

Table A.1 Descriptive statistics

Table A.1: Descriptive statistics

\begin{tabular}{|c|c|c|c|c|c|}
\hline & Mean & SD & Min & Max & $\mathbf{N}$ \\
\hline \multicolumn{6}{|c|}{ A. Health } \\
\hline Mental health (SF-12) & 52.40 & 10.03 & 4.83 & 79.33 & 36,047 \\
\hline \multicolumn{6}{|c|}{ B. Demographic characteristics } \\
\hline Migrant status & 0.10 & 0.30 & 0 & 1 & 36,047 \\
\hline Exogamy & 0.07 & 0.25 & 0 & 1 & 35,977 \\
\hline Age & 69.32 & 6.49 & 60 & 99 & 34,490 \\
\hline Age gap to partner & 1.07 & 5.41 & -26 & 50 & 33,353 \\
\hline Female & 0.45 & 0.50 & 0 & 1 & 36,047 \\
\hline EU origin & 0.95 & 0.22 & 0 & 1 & 36,047 \\
\hline Age at arrival in Germany: 0-11 & 0.00 & 0.05 & 0 & 1 & 35,365 \\
\hline Age at arrival in Germany: $12-17$ & 0.00 & 0.05 & 0 & 1 & 35,365 \\
\hline \multicolumn{6}{|c|}{ C. Geographic characteristics } \\
\hline Living in East Germany & 0.24 & 0.43 & 0 & 1 & 36,047 \\
\hline Living in rural area & 0.35 & 0.48 & 0 & 1 & 36,047 \\
\hline \multicolumn{6}{|c|}{ D. Socioeconomic characteristics } \\
\hline Working & 0.14 & 0.34 & 0 & 1 & 36,047 \\
\hline Years of education & 11.93 & 2.76 & 7 & 18 & 35,373 \\
\hline $\begin{array}{l}\text { Difference in years of education to partner } \\
\text { Income quintile }\end{array}$ & 0.06 & 2.62 & -11 & 11 & 33,326 \\
\hline 1 & 0.28 & 0.45 & 0 & 1 & 36,047 \\
\hline 2 & 0.24 & 0.43 & 0 & 1 & 36,047 \\
\hline 3 & 0.16 & 0.36 & 0 & 1 & 36,047 \\
\hline 4 & 0.12 & 0.33 & 0 & 1 & 36,047 \\
\hline 5 & 0.14 & 0.35 & 0 & 1 & 36,047 \\
\hline Previously divorced & 0.18 & 0.38 & 0 & 1 & 36,030 \\
\hline \multicolumn{6}{|c|}{ E. Social networks } \\
\hline Number of close friends & 4.40 & 4.13 & 0 & 90 & 27,840 \\
\hline Older kin live nearby & 0.14 & 0.35 & 0 & 1 & 23,188 \\
\hline Older kin of the spouse live nearby & 0.16 & 0.37 & 0 & 1 & 22,122 \\
\hline Siblings live nearby & 0.41 & 0.49 & 0 & 1 & 26,248 \\
\hline Siblings of the spouse live nearby & 0.41 & 0.49 & 0 & 1 & 25,109 \\
\hline Younger kin live nearby & 0.60 & 0.49 & 0 & 1 & 25,161 \\
\hline Household size & 2.18 & 0.56 & 2 & 13 & 36,047 \\
\hline Co-residence with child & 0.10 & 0.30 & 0 & 1 & 36,047 \\
\hline
\end{tabular}

Source: SOEPv34, own calculations. 
Table A.2: Analysis of social networks - full sample

\begin{tabular}{|c|c|c|c|c|c|c|c|c|}
\hline & $\begin{array}{l}\text { Number of } \\
\text { close friends }\end{array}$ & $\begin{array}{l}\text { Older kin } \\
\text { live nearby }\end{array}$ & $\begin{array}{l}\text { Older kin of } \\
\text { the spouse } \\
\text { live nearby }\end{array}$ & $\begin{array}{l}\text { Siblings live } \\
\text { nearby }\end{array}$ & $\begin{array}{l}\text { Siblings of } \\
\text { the spouse } \\
\text { live nearby }\end{array}$ & $\begin{array}{l}\text { Younger kin } \\
\text { live nearby }\end{array}$ & $\begin{array}{l}\text { Household } \\
\text { size }\end{array}$ & $\begin{array}{c}\text { Coresidence } \\
\text { with child }\end{array}$ \\
\hline \multirow[t]{2}{*}{ Migrant } & -0.009 & $-0.192 * * *$ & $-0.277 * * *$ & $-0.658 * * *$ & $-0.661 * * *$ & -0.088 & $0.478 * * *$ & $0.429 * * *$ \\
\hline & $(0.061)$ & $(0.037)$ & $(0.043)$ & $(0.050)$ & $(0.054)$ & $(0.060)$ & $(0.094)$ & $(0.084)$ \\
\hline \multirow[t]{2}{*}{ Exogamy } & $-0.069 \dagger$ & $-0.072 *$ & $-0.258 * * *$ & 0.005 & $-0.464 * * *$ & $-0.203 * * *$ & $0.116^{*}$ & 0.078 \\
\hline & $(0.041)$ & $(0.036)$ & $(0.037)$ & $(0.052)$ & $(0.045)$ & $(0.054)$ & $(0.050)$ & $(0.055)$ \\
\hline \multirow[t]{2}{*}{ Migrant x Exogamy } & 0.052 & 0.033 & $0.490 * * *$ & -0.089 & $1.096^{* * *}$ & -0.145 & $-0.603 * * *$ & $-0.448 * * *$ \\
\hline & $(0.088)$ & $(0.056)$ & $(0.076)$ & $(0.078)$ & $(0.094)$ & $(0.103)$ & $(0.112)$ & $(0.125)$ \\
\hline \multirow[t]{2}{*}{ Age } & $0.069^{* *}$ & $-0.195 * * *$ & $-0.179^{* * *}$ & $0.059 * *$ & $0.047^{*}$ & $0.038 \dagger$ & $-0.185^{* * *}$ & $-0.220 * * *$ \\
\hline & $(0.024)$ & $(0.015)$ & $(0.016)$ & $(0.021)$ & $(0.021)$ & $(0.020)$ & $(0.015)$ & $(0.019)$ \\
\hline \multirow[t]{2}{*}{ Age squared } & $-0.001 * * *$ & $0.001 * * *$ & $0.001 * * *$ & $-0.000 * *$ & $-0.000^{*}$ & 0 & $0.001 * * *$ & $0.001 * * *$ \\
\hline & $(0.000)$ & $(0.000)$ & $(0.000)$ & $(0.000)$ & $(0.000)$ & $(0.000)$ & $(0.000)$ & $(0.000)$ \\
\hline \multirow[t]{2}{*}{ Age gap to partner } & $0.027 \dagger$ & 0.014 & $0.111 * * *$ & 0.001 & $0.095 * *$ & 0.001 & 0.005 & 0.015 \\
\hline & $(0.015)$ & $(0.023)$ & $(0.031)$ & $(0.016)$ & $(0.032)$ & $(0.041)$ & $(0.012)$ & $(0.014)$ \\
\hline \multirow[t]{2}{*}{ Female } & $0.072 * * *$ & -0.001 & $-0.051 * *$ & 0.016 & -0.033 & $0.038 \dagger$ & 0.016 & -0.002 \\
\hline & $(0.021)$ & $(0.018)$ & $(0.019)$ & $(0.024)$ & $(0.024)$ & $(0.023)$ & $(0.020)$ & $(0.022)$ \\
\hline \multirow[t]{2}{*}{ EU origin } & $-0.208^{*}$ & 0.025 & 0.101 & 0.001 & -0.066 & 0.101 & -0.01 & $0.121 * *$ \\
\hline & $(0.104)$ & $(0.104)$ & $(0.081)$ & $(0.083)$ & $(0.095)$ & $(0.121)$ & $(0.080)$ & $(0.043)$ \\
\hline \multirow[t]{2}{*}{ Age at arrival in Germany: 0-11 } & 0.181 & 0.363 & 0.156 & $0.598^{* *}$ & 0.135 & 0.299 & -0.014 & -0.152 \\
\hline & $(0.140)$ & $(0.226)$ & $(0.207)$ & $(0.189)$ & $(0.208)$ & $(0.219)$ & $(0.217)$ & $(0.214)$ \\
\hline \multirow[t]{2}{*}{ Age at arrival in Germany: $12-17$} & 0.015 & 0.185 & -0.158 & $0.624 * *$ & 0.039 & 0.214 & $0.610 \dagger$ & 0.274 \\
\hline & $(0.140)$ & $(0.161)$ & $(0.139)$ & $(0.200)$ & $(0.195)$ & $(0.211)$ & $(0.333)$ & $(0.271)$ \\
\hline \multirow[t]{2}{*}{ Living in East Germany } & 0.233 & -0.026 & $-0.254^{*}$ & -0.262 & -0.204 & $-0.543 \dagger$ & 0.136 & 0.162 \\
\hline & $(0.186)$ & $(0.240)$ & $(0.129)$ & $(0.224)$ & $(0.243)$ & $(0.322)$ & $(0.120)$ & $(0.127)$ \\
\hline \multirow[t]{2}{*}{ Living in a rural area } & -0.137 & -0.105 & -0.054 & $-0.498 * * *$ & $-0.407 * *$ & 0.004 & 0.211 & 0.112 \\
\hline & $(0.179)$ & $(0.113)$ & $(0.113)$ & $(0.142)$ & $(0.143)$ & $(0.167)$ & $(0.143)$ & $(0.165)$ \\
\hline \multirow[t]{2}{*}{ East Germany x Rural area } & -0.097 & 0.014 & 0.221 & $0.666^{* *}$ & $0.625^{*}$ & 0.369 & -0.073 & 0.029 \\
\hline & $(0.236)$ & $(0.206)$ & $(0.141)$ & $(0.237)$ & $(0.246)$ & $(0.269)$ & $(0.150)$ & $(0.172)$ \\
\hline \multirow[t]{2}{*}{ Working } & $-0.067 * *$ & 0.037 & 0.026 & 0.003 & -0.015 & $-0.101 * *$ & 0.007 & 0.024 \\
\hline & $(0.026)$ & $(0.032)$ & $(0.035)$ & $(0.031)$ & $(0.033)$ & $(0.034)$ & $(0.021)$ & $(0.025)$ \\
\hline \multirow[t]{2}{*}{ Years of education } & -0.293 & 0.012 & -0.003 & 0.009 & -0.018 & 0.029 & -0.044 & -0.026 \\
\hline & $(0.418)$ & $(0.016)$ & $(0.024)$ & $(0.024)$ & $(0.026)$ & $(0.026)$ & $(0.032)$ & $(0.028)$ \\
\hline \multirow[t]{2}{*}{ Difference in education to partner } & 0.107 & 0.003 & 0.006 & -0.014 & 0.012 & -0.013 & 0.024 & 0.02 \\
\hline & $(0.069)$ & $(0.015)$ & $(0.015)$ & $(0.019)$ & $(0.017)$ & $(0.018)$ & $(0.029)$ & $(0.028)$ \\
\hline \multirow[t]{2}{*}{ Income: 2nd quintile } & 0.013 & 0.007 & 0.007 & -0.016 & -0.01 & -0.006 & $0.045^{* * *}$ & $0.052 * * *$ \\
\hline & $(0.021)$ & $(0.019)$ & $(0.020)$ & $(0.026)$ & $(0.026)$ & $(0.021)$ & $(0.014)$ & $(0.016)$ \\
\hline \multirow[t]{2}{*}{ Income: 3rd quintile } & 0.026 & 0 & -0.008 & -0.036 & -0.016 & -0.009 & $0.110 * * *$ & $0.134 * * *$ \\
\hline & $(0.029)$ & $(0.023)$ & $(0.026)$ & $(0.030)$ & $(0.031)$ & $(0.027)$ & $(0.023)$ & $(0.024)$ \\
\hline
\end{tabular}




\begin{tabular}{|c|c|c|c|c|c|c|c|c|}
\hline \multirow{2}{*}{ Income: 4th quintile } & -0.024 & -0.023 & -0.009 & 0.037 & 0.04 & -0.038 & $0.261 * * *$ & $0.259 * * *$ \\
\hline & $(0.034)$ & $(0.029)$ & $(0.031)$ & $(0.037)$ & $(0.037)$ & $(0.037)$ & $(0.036)$ & $(0.035)$ \\
\hline \multirow[t]{2}{*}{ Income: 5th quintile } & 0.007 & -0.019 & -0.006 & 0.035 & 0.049 & $-0.105^{*}$ & $0.315 * * *$ & $0.312 * * *$ \\
\hline & $(0.037)$ & $(0.036)$ & $(0.037)$ & $(0.043)$ & $(0.044)$ & $(0.051)$ & $(0.048)$ & $(0.046)$ \\
\hline \multirow{2}{*}{ Previously divorced } & 0.045 & -0.155 & $0.084 \dagger$ & -0.095 & 0.175 & -0.15 & -0.046 & $-0.117 *$ \\
\hline & $(0.081)$ & $(0.098)$ & $(0.049)$ & $(0.110)$ & $(0.139)$ & $(0.109)$ & $(0.033)$ & $(0.054)$ \\
\hline \multirow[t]{2}{*}{ Constant } & $-4.752 * * *$ & $12.478 * * *$ & $7.556 * * *$ & $2.663^{*}$ & 1.981 & -1.6 & $5.524 * * *$ & $6.485^{* * * *}$ \\
\hline & $(1.054)$ & $(0.956)$ & $(0.953)$ & $(1.261)$ & $(1.274)$ & $(1.267)$ & $(0.975)$ & $(1.027)$ \\
\hline$N$ & 24,408 & 16,523 & 16,518 & 16,749 & 16,752 & 16,366 & 31,281 & 31,281 \\
\hline
\end{tabular}

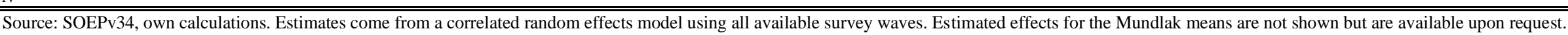
Outcomes are standardized. Standard errors are clustered on the individual level. $\dagger \mathrm{p}<0.1,{ }^{*} \mathrm{p}<0.05,{ }^{* *} \mathrm{p}<0.01 ;{ }^{* * *} \mathrm{p}<0.001$. 
Table A.3: Analysis of social networks - Men

\begin{tabular}{|c|c|c|c|c|c|c|c|c|}
\hline & $\begin{array}{l}\text { Number of } \\
\text { close friends }\end{array}$ & $\begin{array}{c}\text { Older kin live } \\
\text { nearby }\end{array}$ & $\begin{array}{c}\text { Older kin of } \\
\text { the spouse live } \\
\text { nearby }\end{array}$ & $\begin{array}{l}\text { Siblings live } \\
\text { nearby }\end{array}$ & $\begin{array}{c}\text { Siblings of the } \\
\text { spouse live } \\
\text { nearby }\end{array}$ & $\begin{array}{l}\text { Younger kin } \\
\text { live nearby }\end{array}$ & Household size & $\begin{array}{l}\text { Coresidence } \\
\text { with child }\end{array}$ \\
\hline Migrant & $\begin{array}{c}0.012 \\
(0.080)\end{array}$ & $\begin{array}{c}-0.178 * * * \\
(0.053)\end{array}$ & $\begin{array}{c}-0.432 * * * \\
(0.061)\end{array}$ & $\begin{array}{c}-0.697 * * * \\
(0.061)\end{array}$ & $\begin{array}{c}-0.716 * * * \\
(0.073)\end{array}$ & $\begin{array}{l}-0.182^{*} \\
(0.081)\end{array}$ & $\begin{array}{c}0.587 * * * \\
(0.141)\end{array}$ & $\begin{array}{c}0.486 * * * \\
(0.114)\end{array}$ \\
\hline Exogamy & $\begin{array}{l}-0.093 \\
(0.057)\end{array}$ & $\begin{array}{l}-0.063 \\
(0.047)\end{array}$ & $\begin{array}{c}-0.367 * * * \\
(0.056)\end{array}$ & $\begin{array}{c}0.003 \\
(0.069)\end{array}$ & $\begin{array}{c}-0.475 * * * \\
(0.063)\end{array}$ & $\begin{array}{c}-0.257 * * * \\
(0.073)\end{array}$ & $\begin{array}{l}0.138 \dagger \\
(0.072)\end{array}$ & $\begin{array}{c}0.034 \\
(0.075)\end{array}$ \\
\hline Migrant x Exogamy & $\begin{array}{c}0.053 \\
(0.129)\end{array}$ & $\begin{array}{c}0.026 \\
(0.074)\end{array}$ & $\begin{array}{c}0.712 * * * \\
(0.118)\end{array}$ & $\begin{array}{l}-0.112 \\
(0.099)\end{array}$ & $\begin{array}{c}1.078 * * * \\
(0.130)\end{array}$ & $\begin{array}{c}0.041 \\
(0.141)\end{array}$ & $\begin{array}{c}-0.671 * * * \\
(0.164)\end{array}$ & $\begin{array}{c}-0.478 * * \\
(0.173)\end{array}$ \\
\hline Age & $\begin{array}{c}0.086^{* *} \\
(0.033)\end{array}$ & $\begin{array}{c}-0.183^{* * * *} \\
(0.019)\end{array}$ & $\begin{array}{c}-0.231 * * * \\
(0.023)\end{array}$ & $\begin{array}{c}0.031 \\
(0.027)\end{array}$ & $\begin{array}{c}0.043 \\
(0.028)\end{array}$ & $\begin{array}{c}0.029 \\
(0.027)\end{array}$ & $\begin{array}{c}-0.224 * * * \\
(0.021)\end{array}$ & $\begin{array}{c}-0.261^{* * * *} \\
(0.027)\end{array}$ \\
\hline Age squared & $\begin{array}{c}-0.001 * * \\
(0.000)\end{array}$ & $\begin{array}{c}0.001 * * * \\
(0.000)\end{array}$ & $\begin{array}{c}0.001 * * * \\
(0.000)\end{array}$ & $\begin{array}{c}0 \\
(0.000)\end{array}$ & $\begin{array}{l}-0.000 \dagger \\
(0.000)\end{array}$ & $\begin{array}{c}0 \\
(0.000)\end{array}$ & $\begin{array}{c}0.001 * * * \\
(0.000)\end{array}$ & $\begin{array}{c}0.002 * * * \\
(0.000)\end{array}$ \\
\hline Age gap to partner & $\begin{array}{c}0.037 * * \\
(0.014)\end{array}$ & $\begin{array}{c}0.017 \\
(0.025)\end{array}$ & $\begin{array}{c}0.107 * * * \\
(0.029)\end{array}$ & $\begin{array}{l}-0.009 \\
(0.018)\end{array}$ & $\begin{array}{l}0.081^{*} \\
(0.034)\end{array}$ & $\begin{array}{c}0.007 \\
(0.040)\end{array}$ & $\begin{array}{l}-0.001 \\
(0.017)\end{array}$ & $\begin{array}{c}0.013 \\
(0.019)\end{array}$ \\
\hline EU origin & $\begin{array}{l}-0.169 \\
(0.129)\end{array}$ & $\begin{array}{c}0.191 * * * \\
(0.027)\end{array}$ & $\begin{array}{c}0.126 \\
(0.148)\end{array}$ & $\begin{array}{c}0.03 \\
(0.127)\end{array}$ & $\begin{array}{l}-0.212 \dagger \\
(0.128)\end{array}$ & $\begin{array}{c}0.149 \\
(0.198)\end{array}$ & $\begin{array}{l}0.075 \\
(0.070)\end{array}$ & $\begin{array}{c}0.184 * * * \\
(0.034)\end{array}$ \\
\hline Age at arrival in Germany: 0-11 & $\begin{array}{l}-0.038 \\
(0.136)\end{array}$ & $\begin{array}{l}-0.032 \\
(0.165)\end{array}$ & $\begin{array}{c}0.091 \\
(0.291)\end{array}$ & $\begin{array}{l}0.418^{*} \\
(0.193)\end{array}$ & $\begin{array}{c}0.231 \\
(0.271)\end{array}$ & $\begin{array}{c}0.157 \\
(0.277)\end{array}$ & $\begin{array}{c}0.071 \\
(0.315)\end{array}$ & $\begin{array}{c}0.046 \\
(0.311)\end{array}$ \\
\hline Age at arrival in Germany: $12-17$ & $\begin{array}{c}0.154 \\
(0.223)\end{array}$ & $\begin{array}{c}0.232 \\
(0.288)\end{array}$ & $\begin{array}{l}-0.159 \\
(0.261)\end{array}$ & $\begin{array}{c}0.811^{* *} \\
(0.295)\end{array}$ & $\begin{array}{l}0.213 \\
(0.272)\end{array}$ & $\begin{array}{l}0.098 \\
(0.316)\end{array}$ & $\begin{array}{l}1.143^{*} \\
(0.576)\end{array}$ & $\begin{array}{l}0.488 \\
(0.414)\end{array}$ \\
\hline Living in East Germany & $\begin{array}{l}0.496^{*} \\
(0.226)\end{array}$ & $\begin{array}{c}0.121 \\
(0.348)\end{array}$ & $\begin{array}{l}-0.221 \\
(0.180)\end{array}$ & $\begin{array}{c}-0.528 * * \\
(0.177)\end{array}$ & $\begin{array}{l}-0.081 \\
(0.357)\end{array}$ & $\begin{array}{l}-0.621 \\
(0.393)\end{array}$ & $\begin{array}{c}0.183 \\
(0.180)\end{array}$ & $\begin{array}{c}0.194 \\
(0.187)\end{array}$ \\
\hline Living in a rural area & $\begin{array}{l}-0.073 \\
(0.269)\end{array}$ & $\begin{array}{l}-0.079 \\
(0.147)\end{array}$ & $\begin{array}{l}-0.115 \\
(0.202)\end{array}$ & $\begin{array}{c}-0.511^{* *} \\
(0.187)\end{array}$ & $\begin{array}{l}-0.436 * \\
(0.205)\end{array}$ & $\begin{array}{l}-0.009 \\
(0.209)\end{array}$ & $\begin{array}{l}0.318^{*} \\
(0.153)\end{array}$ & $\begin{array}{l}0.286 \dagger \\
(0.164)\end{array}$ \\
\hline East Germany x Rural area & $\begin{array}{l}-0.387 \\
(0.325)\end{array}$ & $\begin{array}{l}-0.145 \\
(0.290)\end{array}$ & $\begin{array}{c}0.275 \\
(0.236)\end{array}$ & $\begin{array}{c}0.664 * * \\
(0.219)\end{array}$ & $\begin{array}{l}0.716 \dagger \\
(0.369)\end{array}$ & $\begin{array}{c}0.345 \\
(0.302)\end{array}$ & $\begin{array}{l}-0.152 \\
(0.193)\end{array}$ & $\begin{array}{l}-0.128 \\
(0.205)\end{array}$ \\
\hline Working & $\begin{array}{c}-0.074^{*} \\
(0.034)\end{array}$ & $\begin{array}{c}0.003 \\
(0.036)\end{array}$ & $\begin{array}{c}0.005 \\
(0.045)\end{array}$ & $\begin{array}{l}-0.016 \\
(0.038)\end{array}$ & $\begin{array}{l}-0.022 \\
(0.038)\end{array}$ & $\begin{array}{l}-0.104 * \\
(0.041)\end{array}$ & $\begin{array}{l}-0.001 \\
(0.028)\end{array}$ & $\begin{array}{c}0.029 \\
(0.033)\end{array}$ \\
\hline Years of education & $\begin{array}{l}-0.277 \\
(0.399)\end{array}$ & $\begin{array}{c}0.029 \\
(0.028)\end{array}$ & $\begin{array}{l}-0.038 \\
(0.035)\end{array}$ & $\begin{array}{c}0.005 \\
(0.034)\end{array}$ & $\begin{array}{c}-0.01 \\
(0.040)\end{array}$ & $\begin{array}{c}0.016 \\
(0.039)\end{array}$ & $\begin{array}{l}-0.056 \\
(0.054)\end{array}$ & $\begin{array}{l}-0.032 \\
(0.046)\end{array}$ \\
\hline Difference in education to partner & $\begin{array}{c}0.091 \\
(0.074)\end{array}$ & $\begin{array}{l}-0.006 \\
(0.028)\end{array}$ & $\begin{array}{l}0.054 * \\
(0.026)\end{array}$ & $\begin{array}{l}-0.011 \\
(0.031)\end{array}$ & $\begin{array}{c}0.004 \\
(0.031)\end{array}$ & $\begin{array}{c}-0.02 \\
(0.032)\end{array}$ & $\begin{array}{c}0.064 \\
(0.053)\end{array}$ & $\begin{array}{c}0.06 \\
(0.048)\end{array}$ \\
\hline Income: 2nd quintile & $\begin{array}{c}0.017 \\
(0.029)\end{array}$ & $\begin{array}{c}0.013 \\
(0.027)\end{array}$ & $\begin{array}{l}-0.003 \\
(0.028)\end{array}$ & $\begin{array}{c}0.02 \\
(0.034)\end{array}$ & $\begin{array}{l}-0.056 \\
(0.035)\end{array}$ & $\begin{array}{l}-0.007 \\
(0.029)\end{array}$ & $\begin{array}{c}0.057^{* *} \\
(0.020)\end{array}$ & $\begin{array}{c}0.064 * * \\
(0.022)\end{array}$ \\
\hline Income: 3rd quintile & $\begin{array}{c}0.055 \\
(0.040)\end{array}$ & $\begin{array}{c}0.023 \\
(0.031)\end{array}$ & $\begin{array}{l}-0.032 \\
(0.036)\end{array}$ & $\begin{array}{l}-0.039 \\
(0.038)\end{array}$ & $\begin{array}{l}-0.046 \\
(0.041)\end{array}$ & $\begin{array}{l}-0.018 \\
(0.038)\end{array}$ & $\begin{array}{c}0.118 * * * \\
(0.033)\end{array}$ & $\begin{array}{c}0.144 * * * \\
(0.033)\end{array}$ \\
\hline Income: 4th quintile & $\begin{array}{l}-0.004 \\
(0.046)\end{array}$ & $\begin{array}{l}-0.009 \\
(0.039)\end{array}$ & $\begin{array}{c}-0.03 \\
(0.044)\end{array}$ & $\begin{array}{c}0.018 \\
(0.048)\end{array}$ & $\begin{array}{l}-0.002 \\
(0.049)\end{array}$ & $\begin{array}{l}-0.045 \\
(0.049)\end{array}$ & $\begin{array}{c}0.291 * * * \\
(0.052)\end{array}$ & $\begin{array}{c}0.285^{* * *} \\
(0.049)\end{array}$ \\
\hline Income: 5 th quintile & $\begin{array}{c}0.028 \\
(0.049)\end{array}$ & $\begin{array}{l}-0.028 \\
(0.044)\end{array}$ & $\begin{array}{c}0.019 \\
(0.056)\end{array}$ & $\begin{array}{c}0.035 \\
(0.056)\end{array}$ & $\begin{array}{c}0.013 \\
(0.056)\end{array}$ & $\begin{array}{l}-0.122 \dagger \\
(0.069)\end{array}$ & $\begin{array}{c}0.346 \text { **** } \\
(0.068)\end{array}$ & $\begin{array}{c}0.334 * * * \\
(0.062)\end{array}$ \\
\hline Previously divorced & $\begin{array}{c}0.021 \\
(0.144)\end{array}$ & $\begin{array}{l}-0.168 \\
(0.127)\end{array}$ & $\begin{array}{c}0.176^{* * * *} \\
(0.036)\end{array}$ & $\begin{array}{l}-0.065 \\
(0.135)\end{array}$ & $\begin{array}{l}0.425^{*} \\
(0.191)\end{array}$ & $\begin{array}{l}-0.275 \\
(0.175)\end{array}$ & $\begin{array}{l}-0.072 \\
(0.069)\end{array}$ & $\begin{array}{c}-0.181 \dagger \\
(0.107)\end{array}$ \\
\hline Constant & $\begin{array}{c}-4.858 * * * \\
(1.414)\end{array}$ & $\begin{array}{c}11.863 * * * \\
(1.203)\end{array}$ & $\begin{array}{c}9.188^{* * *} \\
(1.390)\end{array}$ & $\begin{array}{c}1.315 \\
(1.616)\end{array}$ & $\begin{array}{c}0.85 \\
(1.667)\end{array}$ & $\begin{array}{l}-2.342 \\
(1.648)\end{array}$ & $\begin{array}{c}5.538 * * * \\
(1.374)\end{array}$ & $\begin{array}{c}5.885^{* * * *} \\
(1.400)\end{array}$ \\
\hline$N$ & 13,352 & 9,125 & 9,113 & 9,253 & 9,250 & 9,030 & 17,243 & 17,243 \\
\hline
\end{tabular}

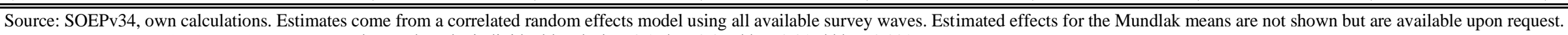
Outcomes are standardized. Standard errors are clustered on the individual level. $\dagger \mathrm{p}<0.1,{ }^{*} \mathrm{p}<0.05,{ }^{* *} \mathrm{p}<0.01 ;{ }^{* * *} \mathrm{p}<0.001$. 
Table A.4: Analysis of social networks - Women

\begin{tabular}{|c|c|c|c|c|c|c|c|c|}
\hline & $\begin{array}{l}\text { Number of } \\
\text { close friends }\end{array}$ & $\begin{array}{l}\text { Older kin } \\
\text { live nearby }\end{array}$ & $\begin{array}{l}\text { Older kin of } \\
\text { the spouse } \\
\text { live nearby }\end{array}$ & $\begin{array}{c}\text { Siblings live } \\
\text { nearby }\end{array}$ & $\begin{array}{l}\text { Siblings of } \\
\text { the spouse } \\
\text { live nearby }\end{array}$ & $\begin{array}{l}\text { Younger kin } \\
\text { live nearby }\end{array}$ & $\begin{array}{l}\text { Household } \\
\text { size }\end{array}$ & $\begin{array}{c}\text { Coresidence } \\
\text { with child }\end{array}$ \\
\hline Migrant & $\begin{array}{l}-0.041 \\
(0.093)\end{array}$ & $\begin{array}{c}-0.212 * * * \\
(0.048)\end{array}$ & $\begin{array}{l}-0.079 \\
(0.055)\end{array}$ & $\begin{array}{c}-0.606 * * * \\
(0.085)\end{array}$ & $\begin{array}{c}-0.583^{* * * *} \\
(0.080)\end{array}$ & $\begin{array}{c}0.041 \\
(0.086)\end{array}$ & $\begin{array}{l}0.332^{* *} \\
(0.105)\end{array}$ & $\begin{array}{l}0.348^{* *} \\
(0.120)\end{array}$ \\
\hline Exogamy & $\begin{array}{l}-0.031 \\
(0.057)\end{array}$ & $\begin{array}{l}-0.084 \\
(0.056)\end{array}$ & $\begin{array}{c}-0.121^{* *} \\
(0.043)\end{array}$ & $\begin{array}{c}0.008 \\
(0.079)\end{array}$ & $\begin{array}{c}-0.457 * * * \\
(0.063)\end{array}$ & $\begin{array}{l}-0.125 \\
(0.078)\end{array}$ & $\begin{array}{c}0.095 \\
(0.064)\end{array}$ & $\begin{array}{l}0.152 \dagger \\
(0.083)\end{array}$ \\
\hline Migrant x Exogamy & $\begin{array}{c}0.04 \\
(0.123)\end{array}$ & $\begin{array}{c}0.024 \\
(0.082)\end{array}$ & $\begin{array}{l}0.223^{*} \\
(0.091)\end{array}$ & $\begin{array}{l}-0.082 \\
(0.121)\end{array}$ & $\begin{array}{c}1.107^{* * *} \\
(0.136)\end{array}$ & $\begin{array}{c}-0.391^{* *} \\
(0.146)\end{array}$ & $\begin{array}{c}-0.458^{* * *} \\
(0.137)\end{array}$ & $\begin{array}{c}-0.383^{*} \\
(0.172)\end{array}$ \\
\hline Age & $\begin{array}{c}0.04 \\
(0.034)\end{array}$ & $\begin{array}{c}-0.219 * * * \\
(0.025)\end{array}$ & $\begin{array}{c}-0.138^{* * *} \\
(0.022)\end{array}$ & $\begin{array}{c}0.103 * * \\
(0.036)\end{array}$ & $\begin{array}{l}0.068^{*} \\
(0.034)\end{array}$ & $\begin{array}{l}0.057 \dagger \\
(0.030)\end{array}$ & $\begin{array}{c}-0.151^{* * *} \\
(0.021)\end{array}$ & $\begin{array}{c}-0.186 * * * \\
(0.027)\end{array}$ \\
\hline Age squared & $\begin{array}{l}-0.000 \dagger \\
(0.000)\end{array}$ & $\begin{array}{c}0.001 * * * \\
(0.000)\end{array}$ & $\begin{array}{c}0.001 * * * \\
(0.000)\end{array}$ & $\begin{array}{c}-0.001 * * \\
(0.000)\end{array}$ & $\begin{array}{l}-0.001^{*} \\
(0.000)\end{array}$ & $\begin{array}{l}-0.000 \dagger \\
(0.000)\end{array}$ & $\begin{array}{c}0.001 * * * \\
(0.000)\end{array}$ & $\begin{array}{c}0.001 * * * \\
(0.000)\end{array}$ \\
\hline Age gap to partner & $\begin{array}{l}-0.363 \\
(0.244)\end{array}$ & $\begin{array}{c}0.127 \\
(0.092)\end{array}$ & $\begin{array}{c}0.037 \\
(0.027)\end{array}$ & $\begin{array}{c}1.794 * * * \\
(0.051)\end{array}$ & $\begin{array}{l}0.072^{*} \\
(0.034)\end{array}$ & $\begin{array}{l}-0.105 \\
(0.114)\end{array}$ & $\begin{array}{l}0.071 \dagger \\
(0.043)\end{array}$ & $\begin{array}{l}0.069 \dagger \\
(0.041)\end{array}$ \\
\hline EU origin & $\begin{array}{l}-0.259 \\
(0.169)\end{array}$ & $\begin{array}{l}-0.135 \\
(0.193)\end{array}$ & $\begin{array}{c}0.067 \\
(0.073)\end{array}$ & $\begin{array}{l}-0.015 \\
(0.107)\end{array}$ & $\begin{array}{c}0.072 \\
(0.136)\end{array}$ & $\begin{array}{c}0.069 \\
(0.140)\end{array}$ & $\begin{array}{l}-0.113 \\
(0.147)\end{array}$ & $\begin{array}{c}0.039 \\
(0.084)\end{array}$ \\
\hline Age at arrival in Germany: 0-11 & $\begin{array}{l}0.560^{*} \\
(0.256)\end{array}$ & $\begin{array}{l}1.120^{*} \\
(0.461)\end{array}$ & $\begin{array}{c}0.221 \\
(0.277)\end{array}$ & $\begin{array}{l}0.996^{* *} \\
(0.359)\end{array}$ & $\begin{array}{l}0.014 \\
(0.317)\end{array}$ & $\begin{array}{l}0.534 \dagger \\
(0.321)\end{array}$ & $\begin{array}{l}-0.272 \dagger \\
(0.161)\end{array}$ & $\begin{array}{c}-0.555^{* * *} \\
(0.137)\end{array}$ \\
\hline Age at arrival in Germany: $12-17$ & $\begin{array}{l}-0.112 \\
(0.154)\end{array}$ & $\begin{array}{c}0.147 \\
(0.152)\end{array}$ & $\begin{array}{c}-0.247^{* *} \\
(0.087)\end{array}$ & $\begin{array}{c}0.419 \\
(0.273)\end{array}$ & $\begin{array}{l}-0.143 \\
(0.279)\end{array}$ & $\begin{array}{c}0.277 \\
(0.288)\end{array}$ & $\begin{array}{c}0.078 \\
(0.201)\end{array}$ & $\begin{array}{c}0.043 \\
(0.335)\end{array}$ \\
\hline Living in East Germany & $\begin{array}{l}-0.229 \\
(0.283)\end{array}$ & $\begin{array}{l}-0.291 \\
(0.196)\end{array}$ & $\begin{array}{l}-0.189 \\
(0.160)\end{array}$ & $\begin{array}{c}0.209 \\
(0.531)\end{array}$ & $\begin{array}{l}-0.409^{*} \\
(0.196)\end{array}$ & $\begin{array}{l}-0.443 \\
(0.540)\end{array}$ & $\begin{array}{c}0.089 \\
(0.145)\end{array}$ & $\begin{array}{c}0.124 \\
(0.159)\end{array}$ \\
\hline Living in a rural area & $\begin{array}{l}-0.243 \\
(0.233)\end{array}$ & $\begin{array}{l}-0.147 \\
(0.176)\end{array}$ & $\begin{array}{c}0.017 \\
(0.050)\end{array}$ & $\begin{array}{l}-0.472 * \\
(0.206)\end{array}$ & $\begin{array}{l}-0.376 \dagger \\
(0.194)\end{array}$ & $\begin{array}{c}0.024 \\
(0.267)\end{array}$ & $\begin{array}{c}0.115 \\
(0.248)\end{array}$ & $\begin{array}{l}-0.062 \\
(0.293)\end{array}$ \\
\hline East Germany x Rural area & $\begin{array}{c}0.376 \\
(0.327)\end{array}$ & $\begin{array}{c}0.28 \\
(0.208)\end{array}$ & $\begin{array}{c}0.065 \\
(0.089)\end{array}$ & $\begin{array}{c}0.568 \\
(0.525)\end{array}$ & $\begin{array}{l}0.549^{*} \\
(0.223)\end{array}$ & $\begin{array}{c}0.412 \\
(0.487)\end{array}$ & $\begin{array}{l}-0.025 \\
(0.225)\end{array}$ & $\begin{array}{c}0.17 \\
(0.267)\end{array}$ \\
\hline Working & $\begin{array}{l}-0.055 \\
(0.040)\end{array}$ & $\begin{array}{l}0.127 \dagger \\
(0.069)\end{array}$ & $\begin{array}{l}-0.027 \\
(0.047)\end{array}$ & $\begin{array}{c}0.034 \\
(0.056)\end{array}$ & $\begin{array}{c}0.034 \\
(0.066)\end{array}$ & $\begin{array}{l}-0.083 \\
(0.065)\end{array}$ & $\begin{array}{l}-0.02 \\
(0.031)\end{array}$ & $\begin{array}{l}-0.035 \\
(0.034)\end{array}$ \\
\hline Years of education & $\begin{array}{l}0 \\
(.)\end{array}$ & $\begin{array}{l}-0.019 \\
(0.019)\end{array}$ & $\begin{array}{l}0.003 \\
(0.030)\end{array}$ & $\begin{array}{c}0.016 \\
(0.042)\end{array}$ & $\begin{array}{l}-0.022 \\
(0.037)\end{array}$ & $\begin{array}{l}0.071 \dagger \\
(0.036)\end{array}$ & $\begin{array}{l}-0.056 \\
(0.041)\end{array}$ & $\begin{array}{l}-0.055 \\
(0.042)\end{array}$ \\
\hline Difference in education to partner & $\begin{array}{c}0.624^{* * *} \\
(0.102)\end{array}$ & $\begin{array}{l}0.005 \\
(0.014)\end{array}$ & $\begin{array}{l}-0.032 \dagger \\
(0.018)\end{array}$ & $\begin{array}{l}-0.014 \\
(0.024)\end{array}$ & $\begin{array}{c}0.02 \\
(0.020)\end{array}$ & $\begin{array}{l}-0.004 \\
(0.019)\end{array}$ & $\begin{array}{l}-0.027^{*} \\
(0.012)\end{array}$ & $\begin{array}{l}-0.035 \dagger \\
(0.018)\end{array}$ \\
\hline Income: 2 nd quintile & $\begin{array}{c}0.01 \\
(0.029)\end{array}$ & $\begin{array}{c}0 \\
(0.025)\end{array}$ & $\begin{array}{c}0.018 \\
(0.030)\end{array}$ & $\begin{array}{l}-0.061 \\
(0.039)\end{array}$ & $\begin{array}{c}0.048 \\
(0.038)\end{array}$ & $\begin{array}{l}-0.006 \\
(0.031)\end{array}$ & $\begin{array}{l}0.029 \dagger \\
(0.017)\end{array}$ & $\begin{array}{l}0.036 \dagger \\
(0.021)\end{array}$ \\
\hline Income: 3rd quintile & $\begin{array}{l}-0.012 \\
(0.041)\end{array}$ & $\begin{array}{l}-0.033 \\
(0.032)\end{array}$ & $\begin{array}{c}0.022 \\
(0.036)\end{array}$ & $\begin{array}{l}-0.034 \\
(0.049)\end{array}$ & $\begin{array}{c}0.028 \\
(0.045)\end{array}$ & $\begin{array}{c}0.002 \\
(0.039)\end{array}$ & $\begin{array}{c}0.095^{* *} \\
(0.030)\end{array}$ & $\begin{array}{c}0.116^{* * * *} \\
(0.035)\end{array}$ \\
\hline Income: 4th quintile & $\begin{array}{l}-0.048 \\
(0.049)\end{array}$ & $\begin{array}{l}-0.038 \\
(0.043)\end{array}$ & $\begin{array}{l}0.015 \\
(0.041)\end{array}$ & $\begin{array}{c}0.066 \\
(0.059)\end{array}$ & $\begin{array}{l}0.098 \dagger \\
(0.058)\end{array}$ & $\begin{array}{l}-0.025 \\
(0.057)\end{array}$ & $\begin{array}{c}0.214 * * * \\
(0.046)\end{array}$ & $\begin{array}{c}0.217^{* * *} \\
(0.050)\end{array}$ \\
\hline Income: 5 th quintile & $\begin{array}{l}-0.019 \\
(0.055)\end{array}$ & $\begin{array}{c}0.001 \\
(0.061)\end{array}$ & $\begin{array}{l}-0.051 \\
(0.040)\end{array}$ & $\begin{array}{c}0.033 \\
(0.065)\end{array}$ & $\begin{array}{c}0.099 \\
(0.071)\end{array}$ & $\begin{array}{l}-0.075 \\
(0.073)\end{array}$ & $\begin{array}{c}0.263 * * * \\
(0.063)\end{array}$ & $\begin{array}{c}0.270 * * * \\
(0.065)\end{array}$ \\
\hline Previously divorced & $\begin{array}{c}0.05 \\
(0.098)\end{array}$ & $\begin{array}{l}-0.119 \\
(0.152)\end{array}$ & $\begin{array}{l}-0.032 \\
(0.101)\end{array}$ & $\begin{array}{l}-0.131 \\
(0.183)\end{array}$ & $\begin{array}{l}-0.154 \\
(0.176)\end{array}$ & $\begin{array}{l}-0.016 \\
(0.107)\end{array}$ & $\begin{array}{l}-0.041 \\
(0.034)\end{array}$ & $\begin{array}{l}-0.089 \\
(0.059)\end{array}$ \\
\hline Constant & $\begin{array}{c}-5.410^{* * * *} \\
(1.626)\end{array}$ & $\begin{array}{c}13.339^{* * *} \\
(1.626)\end{array}$ & $\begin{array}{c}7.271^{* * *} \\
(1.301)\end{array}$ & $\begin{array}{l}4.443 * \\
(2.120)\end{array}$ & $\begin{array}{c}3.204 \\
(2.028)\end{array}$ & $\begin{array}{l}-0.721 \\
(2.066)\end{array}$ & $\begin{array}{c}6.236 * * * \\
(1.449)\end{array}$ & $\begin{array}{c}8.020 * * * \\
(1.567)\end{array}$ \\
\hline$N$ & 11,056 & 7,398 & 7,405 & 7,496 & 7,502 & 7,336 & 14,038 & 14,038 \\
\hline
\end{tabular}

Source: SOEPv34, own calculations. Estimates come from a correlated random effects model using all available survey waves. Estimated effects for the Mundlak means are not shown but are available upon request. Outcomes are standardized. Standard errors are clustered on the individual level. $\dagger \mathrm{p}<0.1,{ }^{*} \mathrm{p}<0.05, * * \mathrm{p}<0.01 ; * * * \mathrm{p}<0.001$. 
Table A.5: Analysis of mental health - full sample

\begin{tabular}{|c|c|c|c|}
\hline & Basic model & $\begin{array}{c}\text { + demographic and geographic } \\
\text { covariates }\end{array}$ & + socioeconomic covariates \\
\hline \multirow[t]{2}{*}{ Migrant } & $-1.945^{* * *}$ & $-1.925 * *$ & $-1.078 \dagger$ \\
\hline & $(0.324)$ & $(0.586)$ & $(0.601)$ \\
\hline \multirow[t]{2}{*}{ Exogamy } & $-0.755 \dagger$ & $-1.033^{*}$ & -0.645 \\
\hline & $(0.453)$ & $(0.465)$ & $(0.466)$ \\
\hline \multirow[t]{2}{*}{ Migrant x Exogamy } & $1.605^{*}$ & 0.852 & -0.295 \\
\hline & $(0.706)$ & $(0.925)$ & $(0.935)$ \\
\hline \multirow[t]{2}{*}{ Age } & & $2.755^{* * *}$ & $2.604 * * *$ \\
\hline & & $(0.213)$ & $(0.223)$ \\
\hline \multirow[t]{2}{*}{ Age squared } & & $-0.021 * * *$ & $-0.020 * * *$ \\
\hline & & $(0.002)$ & $(0.002)$ \\
\hline \multirow[t]{2}{*}{ Age gap to partner } & & 0.027 & 0.154 \\
\hline & & $(0.245)$ & $(0.253)$ \\
\hline \multirow[t]{2}{*}{ Female } & & $-1.958 * * *$ & $-1.644 * * *$ \\
\hline & & $(0.204)$ & $(0.217)$ \\
\hline \multirow[t]{2}{*}{ EU origin } & & 0.28 & 0.391 \\
\hline & & $(0.847)$ & $(0.860)$ \\
\hline \multirow[t]{2}{*}{ Age at arrival in Germany: 0-11 } & & $3.295 \dagger$ & $3.275^{*}$ \\
\hline & & $(1.696)$ & $(1.655)$ \\
\hline \multirow[t]{2}{*}{ Age at arrival in Germany: $12-17$} & & 2.416 & 2.115 \\
\hline & & $(1.581)$ & $(1.564)$ \\
\hline \multirow[t]{2}{*}{ Living in East Germany } & & 3.195 & 3.028 \\
\hline & & $(2.019)$ & $(2.079)$ \\
\hline \multirow[t]{2}{*}{ Living in a rural area } & & -1.358 & -1.739 \\
\hline & & $(1.265)$ & $(1.269)$ \\
\hline \multirow[t]{2}{*}{ East Germany x Rural area } & & $-3.833 \dagger$ & -3.601 \\
\hline & & $(2.208)$ & $(2.279)$ \\
\hline \multirow[t]{2}{*}{ Working } & & & $-1.085^{* * *}$ \\
\hline & & & $(0.228)$ \\
\hline \multirow[t]{2}{*}{ Years of education } & & & -0.091 \\
\hline & & & $(0.228)$ \\
\hline \multirow[t]{2}{*}{ Difference in education to partner } & & & -0.012 \\
\hline & & & $(0.041)$ \\
\hline \multirow[t]{2}{*}{ Income: 2nd quintile } & & & -0.088 \\
\hline & & & $(0.184)$ \\
\hline \multirow[t]{2}{*}{ Income: 3rd quintile } & & & 0.352 \\
\hline & & & $(0.233)$ \\
\hline \multirow[t]{2}{*}{ Income: 4th quintile } & & & $0.761 * *$ \\
\hline & & & $(0.274)$ \\
\hline \multirow[t]{2}{*}{ Income: 5 th quintile } & & & 0.486 \\
\hline & & & $(0.309)$ \\
\hline \multirow[t]{2}{*}{ Previously divorced } & & & $-2.884 * * *$ \\
\hline & & & $(0.675)$ \\
\hline \multirow[t]{2}{*}{ Constant } & $52.357 * * *$ & 2.638 & $-28.329 *$ \\
\hline & $(0.088)$ & (11.493) & $(12.304)$ \\
\hline$N$ & 35,977 & 32,727 & 31,281 \\
\hline
\end{tabular}

Source: SOEPv34, own calculations. Estimates come from a correlated random effects model using the years 2002-2016. Estimated effects for the Mundlak means are not shown but are available upon request. Standard errors are clustered on the individual level. $\dagger \mathrm{p}<0.1,{ }^{*} \mathrm{p}<0.05,{ }^{* *} \mathrm{p}<0.01 ;{ }^{* * *} \mathrm{p}<0.001$. 
Table A.6: Analysis of mental health by gender

\begin{tabular}{|c|c|c|c|c|c|c|}
\hline & \multicolumn{2}{|c|}{ Basic model } & \multicolumn{2}{|c|}{$\begin{array}{l}\text { + demographic and geographic } \\
\text { covariates }\end{array}$} & \multicolumn{2}{|c|}{ + socioeconomic covariates } \\
\hline & Men & Women & Men & Women & Men & Women \\
\hline \multirow[t]{2}{*}{ Migrant } & $-1.778^{* * *}$ & $-2.343 * * *$ & $-1.667 *$ & $-2.229 *$ & -0.865 & -1.441 \\
\hline & $(0.421)$ & $(0.498)$ & $(0.746)$ & $(0.937)$ & $(0.747)$ & $(0.987)$ \\
\hline \multirow[t]{2}{*}{ Exogamy } & 0.098 & $-2.157 * *$ & -0.179 & $-2.121 * *$ & 0.257 & $-1.743 *$ \\
\hline & $(0.576)$ & $(0.683)$ & $(0.616)$ & $(0.680)$ & $(0.616)$ & $(0.686)$ \\
\hline \multirow[t]{2}{*}{ Migrant x Exogamy } & 0.591 & $3.466^{* *}$ & -0.561 & $2.649 \dagger$ & -1.382 & 1.139 \\
\hline & $(0.913)$ & $(1.069)$ & (1.234) & $(1.383)$ & $(1.242)$ & $(1.403)$ \\
\hline \multirow[t]{2}{*}{ Age } & & & $2.834 * * *$ & $2.626 * * *$ & $2.603^{* * *}$ & $2.534 * * *$ \\
\hline & & & $(0.273)$ & $(0.344)$ & $(0.288)$ & $(0.357)$ \\
\hline \multirow[t]{2}{*}{ Age squared } & & & $-0.022 * * *$ & $-0.020 * * *$ & $-0.020 * * *$ & $-0.019 * * *$ \\
\hline & & & $(0.002)$ & $(0.002)$ & $(0.002)$ & $(0.003)$ \\
\hline \multirow[t]{2}{*}{ Age gap to partner } & & & -0.129 & $3.946 * * *$ & 0.007 & $4.209 * * *$ \\
\hline & & & $(0.192)$ & $(1.105)$ & $(0.208)$ & $(0.956)$ \\
\hline \multirow[t]{2}{*}{ EU origin } & & & 0.642 & -0.083 & 0.642 & 0.141 \\
\hline & & & $(1.376)$ & $(0.973)$ & $(1.388)$ & $(0.985)$ \\
\hline \multirow[t]{2}{*}{ Age at arrival in Germany: 0-11 } & & & $3.832 \dagger$ & 2.621 & $3.802 *$ & 2.861 \\
\hline & & & $(2.070)$ & $(2.933)$ & $(1.921)$ & $(3.013)$ \\
\hline \multirow[t]{2}{*}{ Age at arrival in Germany: $12-17$} & & & 2.762 & 2.108 & 2.263 & 2.221 \\
\hline & & & $(2.510)$ & $(2.009)$ & $(2.523)$ & $(1.981)$ \\
\hline \multirow[t]{2}{*}{ Living in East Germany } & & & 1.007 & $7.435 \dagger$ & 1.221 & $6.802 \dagger$ \\
\hline & & & $(2.021)$ & $(3.873)$ & $(2.087)$ & (3.947) \\
\hline \multirow[t]{2}{*}{ Living in a rural area } & & & -1.184 & -0.902 & -1.521 & -1.2 \\
\hline & & & $(1.286)$ & $(2.089)$ & $(1.295)$ & $(2.073)$ \\
\hline \multirow[t]{2}{*}{ East Germany x Rural area } & & & -2.871 & $-7.095 \dagger$ & -2.86 & $-6.695 \dagger$ \\
\hline & & & $(2.368)$ & $(3.907)$ & $(2.456)$ & $(3.981)$ \\
\hline \multirow[t]{2}{*}{ Working } & & & & & $-1.257 * * *$ & $-0.742 \dagger$ \\
\hline & & & & & $(0.277)$ & $(0.410)$ \\
\hline \multirow[t]{2}{*}{ Years of education } & & & & & -0.113 & -0.016 \\
\hline & & & & & $(0.246)$ & $(0.486)$ \\
\hline \multirow[t]{2}{*}{ Difference in education to partner } & & & & & -0.017 & 0.014 \\
\hline & & & & & $(0.058)$ & $(0.060)$ \\
\hline \multirow[t]{2}{*}{ Income: 2nd quintile } & & & & & 0.059 & -0.25 \\
\hline & & & & & $(0.244)$ & $(0.280)$ \\
\hline \multirow[t]{2}{*}{ Income: 3rd quintile } & & & & & 0.278 & 0.455 \\
\hline & & & & & $(0.312)$ & $(0.351)$ \\
\hline \multirow[t]{2}{*}{ Income: 4th quintile } & & & & & $0.703 \dagger$ & $0.852 *$ \\
\hline & & & & & $(0.359)$ & $(0.424)$ \\
\hline \multirow[t]{2}{*}{ Income: 5th quintile } & & & & & 0.234 & $0.883 \dagger$ \\
\hline & & & & & $(0.390)$ & $(0.504)$ \\
\hline \multirow[t]{2}{*}{ Previously divorced } & & & & & $-2.804 * *$ & $-3.005^{* * *}$ \\
\hline & & & & & $(1.000)$ & $(0.891)$ \\
\hline Constant & $53.184 * * *$ & $51.390 * * *$ & -12.421 & 14.123 & $-43.546^{* *}$ & -21.445 \\
\hline & $(0.117)$ & $(0.131)$ & $(14.666)$ & (19.153) & $(16.214)$ & $(19.833)$ \\
\hline$N$ & 19,916 & 16,061 & 18111 & 14,616 & 17243 & 14,038 \\
\hline
\end{tabular}

Source: SOEPv34, own calculations. Estimates come from a correlated random effects model using the years 2002-2016. Estimated effects for the Mundlak means are not shown but are available upon request. Standard errors are clustered on the individual level. $\dagger \mathrm{p}<0.1,{ }^{*} \mathrm{p}<0.05,{ }^{* *} \mathrm{p}<0.01 ;{ }^{* * *} \mathrm{p}<0.001$. 


\section{Migrant}

Exogamy

Migrant x Exogamy

Age

Age squared

Age gap to partner

Female

EU origin

Age at arrival in Germany: 0-11

Age at arrival in Germany: 12-17

Living in East Germany

Living in a rural area

East Germany x Rural area

Working

Years of education

Difference in education to partner

Income: 2nd quintile

Income: 3rd quintile

Income: 4th quintile

Income: 5 th quintile

Previously divorced

Close friends

Older kin close

Partner's older kin close

Siblings close

Partner's siblings close

Younger kin close

Household size

Co-residence with child

Constant
$-0.402$
(0.653)
$-0.788$
(0.493)
$-1.243$
(1.030)
$2.102 * * *$
(0.282)
$-0.016 * * *$
(0.002)
0.102
(0.231)
$-1.638 * * *$
(0.241)
$-0.548$
(1.450)
$3.390 \dagger$
(1.983)
2.64
(1.878)
1.176
(2.897)
$-2.064$
(1.734)
$-3.738$
(3.056)
$-1.500 * * *$
(0.326)
$-0.57$
(0.369)
$0.480 \dagger$
(0.292)
0.108
(0.270)
$0.970 * *$
(0.340)
$1.594 * * *$
(0.415)
$1.433 * *$
(0.464)
$-2.463 * *$
(0.900)

$-0.165$

(0.737)

$-0.969 \dagger$

(0.520)

$-1.371$

(1.096)

$1.647 * * *$

(0.327)

$-0.013 * * *$

(0.002)

0.079

(0.305)

$-1.655 * * *$

(0.253)

$-0.531$

(1.824)

$3.738 \dagger$

(2.149)

2.506

(1.985)

3.055

(3.550)

$-0.92$

(1.844)

$-6.560 \dagger$

(3.713)

$-1.689 * * *$

(0.369)

$-1.340 * *$

(0.480)

$1.128 * *$

(0.374)

0.23

(0.301)

$1.261 * * *$

(0.370)

$2.019 * * *$

(0.466)

$2.104 * * *$

(0.522)

$-0.991$

(1.102)

0.035

(0.030)

$-1.511 * *$

(0.528)

$-0.77$

(0.468)

$-0.224$

(0.333)

$-0.032$

(0.342)

0.187

(0.364)

$-0.067$

(0.579)

$-0.317$

(0.825)

$-7.352$

(16.215) $\mathrm{p}<0.05$, ** $\mathrm{p}<0.01 ; * * * \mathrm{p}<0.001$. 
Migrant

Exogamy

Migrant x Exogamy

Age

Age squared

Age gap to partner

EU origin

Age at arrival in Germany: 0-11

Age at arrival in Germany: 12-17

Living in East Germany

Living in a rural area

East Germany x Rural area

Working

Years of education

Difference in education to partner

Income: 2nd quintile

Income: 3rd quintile

Income: 4th quintile

Income: 5th quintile

Previously divorced

Older kin close

Partner's older kin close

Siblings close

Partner's siblings close

Younger kin close

Household size

Co-residence with child

Constant
Close friends

Table A.8: Mental health and social networksby gender

\begin{tabular}{|c|c|c|c|}
\hline \multicolumn{2}{|c|}{ Men } & \multicolumn{2}{|c|}{ Women } \\
\hline $\begin{array}{c}\text { CRE w/o social } \\
\text { networks }\end{array}$ & $\begin{array}{c}\text { CRE w/ social } \\
\text { networks }\end{array}$ & $\begin{array}{c}\text { CRE w/o social } \\
\text { networks }\end{array}$ & $\begin{array}{c}\text { CRE w/ social } \\
\text { networks }\end{array}$ \\
\hline-0.481 & -0.79 & -0.414 & 0.506 \\
\hline$(0.807)$ & $(0.929)$ & $(1.080)$ & (1.196) \\
\hline 0.05 & -0.016 & $-1.819 *$ & $-2.093 * *$ \\
\hline$(0.673)$ & $(0.705)$ & $(0.713)$ & $(0.764)$ \\
\hline-2.173 & -1.87 & 0.031 & -0.624 \\
\hline (1.357) & $(1.449)$ & (1.554) & (1.676) \\
\hline $2.114 * * *$ & $1.833 * * *$ & $2.075 * * *$ & $1.267^{*}$ \\
\hline$(0.364)$ & $(0.421)$ & $(0.456)$ & $(0.538)$ \\
\hline$-0.016^{* * * *}$ & $-0.014 * * *$ & $-0.016^{* * * *}$ & $-0.010 * *$ \\
\hline$(0.003)$ & $(0.003)$ & $(0.003)$ & $(0.004)$ \\
\hline 0.036 & 0.24 & 1.587 & -1.872 \\
\hline$(0.233)$ & $(0.349)$ & (2.239) & $(2.060)$ \\
\hline-1.231 & -1.187 & 0.253 & 0.172 \\
\hline (2.497) & (3.114) & (1.526) & (1.655) \\
\hline $5.128^{*}$ & $6.902 * * *$ & 1.044 & -1.472 \\
\hline$(2.338)$ & $(2.050)$ & (3.414) & (4.274) \\
\hline 1.538 & 1.028 & $3.692 \dagger$ & 3.192 \\
\hline$(3.212)$ & $(3.662)$ & $(2.130)$ & $(2.161)$ \\
\hline-0.797 & 2.263 & 7.204 & 6.172 \\
\hline$(2.476)$ & (3.214) & (7.787) & (8.336) \\
\hline-2.249 & -0.61 & -1.358 & -0.717 \\
\hline (2.053) & (2.145) & (2.887) & $(3.181)$ \\
\hline-2.314 & -4.913 & -9.248 & -10.947 \\
\hline$(3.101)$ & $(3.739)$ & (7.337) & (7.988) \\
\hline$-1.636 * * *$ & $-1.972 * * *$ & $-1.197 *$ & -1.024 \\
\hline$(0.395)$ & $(0.443)$ & $(0.601)$ & $(0.679)$ \\
\hline-0.425 & $-1.118 \dagger$ & -0.58 & $-1.392 \dagger$ \\
\hline$(0.505)$ & $(0.669)$ & $(0.624)$ & $(0.828)$ \\
\hline 0.233 & 0.861 & $0.767^{*}$ & $1.377 * *$ \\
\hline$(0.452)$ & $(0.587)$ & $(0.382)$ & $(0.489)$ \\
\hline 0.288 & 0.348 & -0.073 & 0.12 \\
\hline$(0.357)$ & $(0.388)$ & $(0.414)$ & $(0.472)$ \\
\hline 0.662 & $0.896 \dagger$ & $1.398 * *$ & $1.754 * *$ \\
\hline$(0.452)$ & $(0.492)$ & $(0.518)$ & $(0.562)$ \\
\hline $1.411^{* *}$ & $1.884^{* *}$ & $1.846^{* * *}$ & $2.227 * *$ \\
\hline$(0.542)$ & $(0.601)$ & $(0.646)$ & $(0.737)$ \\
\hline $1.407^{*}$ & $2.075^{* *}$ & $1.518^{*}$ & $2.254 * *$ \\
\hline$(0.596)$ & $(0.654)$ & $(0.738)$ & $(0.855)$ \\
\hline-2.01 & -2.072 & $-2.947 *$ & -0.461 \\
\hline (1.295) & (1.518) & (1.235) & (1.603) \\
\hline & 0.012 & & 0.078 \\
\hline & $(0.034)$ & & $(0.053)$ \\
\hline & -0.363 & & $-2.934 * * *$ \\
\hline & $(0.739)$ & & $(0.754)$ \\
\hline & $-0.932 \dagger$ & & -0.493 \\
\hline & $(0.559)$ & & $(0.882)$ \\
\hline & -0.312 & & -0.111 \\
\hline & $(0.448)$ & & $(0.497)$ \\
\hline & 0.367 & & -0.569 \\
\hline & $(0.452)$ & & $(0.529)$ \\
\hline & -0.227 & & 0.841 \\
\hline & $(0.458)$ & & $(0.603)$ \\
\hline & 0.756 & & $-1.662 \dagger$ \\
\hline & $(0.744)$ & & $(0.928)$ \\
\hline & -1.491 & & 1.912 \\
\hline & (1.023) & & (1.394) \\
\hline$-52.288 * *$ & -34.018 & -1.005 & 20.423 \\
\hline (18.683) & (21.374) & $(22.445)$ & (26.556) \\
\hline 8,769 & 7,155 & 7,131 & 5,797 \\
\hline
\end{tabular}

\begin{tabular}{lcr}
$N$ & 8,769 & 7,155 \\
\hline \hline Source: SOEPv34, own calculations. Standard errors are clustered on the individual level M
\end{tabular}

7,131

5,797 $\mathrm{p}<0.1, * \mathrm{p}<0.05, * * \mathrm{p}<0.01 ; * * * \mathrm{p}<0.001$ 
Table A.9: Panel attrition and union dissolution

Remains in sample in $\mathbf{t}+1$

\begin{tabular}{|c|c|c|c|c|c|c|}
\hline \multirow{3}{*}{ Migrant } & 1 & 2 & 3 & 1 & 2 & 3 \\
\hline & $-0.061 * * *$ & $-0.107 * * *$ & -0.01 & $-0.063 * * *$ & $-0.123 * * *$ & -0.012 \\
\hline & $(0.010)$ & $(0.019)$ & $(0.016)$ & $(0.011)$ & $(0.022)$ & $(0.020)$ \\
\hline \multirow[t]{2}{*}{ Exogamy } & $-0.032 *$ & -0.024 & -0.014 & $-0.046^{* *}$ & $-0.041^{*}$ & -0.032 \\
\hline & $(0.012)$ & $(0.015)$ & $(0.012)$ & $(0.016)$ & $(0.019)$ & $(0.017)$ \\
\hline \multirow[t]{2}{*}{ Migrant x Exogamy } & $0.068 * * *$ & $0.082 * *$ & 0.03 & $0.081 * * *$ & $0.117 * * *$ & $0.061^{*}$ \\
\hline & $(0.019)$ & $(0.028)$ & $(0.023)$ & $(0.024)$ & $(0.034)$ & $(0.030)$ \\
\hline \multirow{2}{*}{ Constant } & $0.675 * * *$ & 0.386 & $-6.817 * * *$ & $0.620 * * *$ & $0.975 * *$ & $-5.806 * * *$ \\
\hline & $(0.002)$ & $(0.288)$ & $(0.368)$ & $(0.003)$ & $(0.296)$ & $(0.409)$ \\
\hline$N$ & 35,977 & 33,346 & 31,769 & 35,977 & 33,346 & 31,769 \\
\hline Random effects & yes & yes & yes & yes & yes & yes \\
\hline Covariates & no & yes & yes & no & yes & yes \\
\hline Mundlak means & no & no & yes & no & no & yes \\
\hline
\end{tabular}

Source: SOEPv34, own calculations. Model 1 presents estimates from a random effects model without additional covariates. Model 2 additionally includes controls for age, squared age, gender, EU origin, age at arrival in Germany, East Germany, rural area, an interaction between East Germany and rural area, working status, education in years, income in quintiles, household size and coresidence with a child. Model 3 presents estimates from a correlated random effects model with the covariates mentioned above using the Mundlak approach. The dependent variable for the estimates in the left panel is defined as 1 if the individual is still observed in $\mathrm{t}+1$ and 0 otherwise. The dependent variable in the panel on the right-hand side is defined as 1 if an individual is observed in $t+1$ and has the same partner as in $t$, and 0 if the individual is observed in $t+1$ but with a different partner. Significance: $\dagger \mathrm{p}<0.1,{ }^{*} \mathrm{p}<0.05,{ }^{* *} \mathrm{p}<0.01 ; * * * \mathrm{p}<0.001$. 